\title{
Development and Application of Heterogeneous Catalyst from Snail Shells for Optimization of Biodiesel Production from Moringa Oleifera Seed Oil
}

\author{
Ameh Charles Ugbede ${ }^{1, ~ *, ~ E t e r i g h o ~ E l i z a b e t h ~ J u m o k e ~}{ }^{1}$, Musa Abdullahi Abdullahi² \\ ${ }^{1}$ Department of Chemical Engineering, School Engineering and Engineering Technology, Federal University of Technology, Minna, Nigeria \\ ${ }^{2}$ Department of Production, Process and Utilities, Dangote Fertiliser Ltd, Lagos, Nigeria
}

\section{Email address:}

engineerameh@gmail.com (A. C. Ugbede), jummyeterigho@yahoo.com (E. E. Jumoke), abdunmalam@gmail.com (M. A. Abdullahi)

${ }^{*}$ Corresponding author

\section{To cite this article:}

Ameh Charles Ugbede, Eterigho Elizabeth Jumoke, Musa Abdullahi Abdullahi. Development and Application of Heterogeneous Catalyst from Snail Shells for Optimization of Biodiesel Production from Moringa Oleifera Seed Oil. American Journal of Chemical Engineering. Vol. 9, No. 1, 2021, pp. 1-17. doi: 10.11648/j.ajche.20210901.11

Received: January 9, 2021; Accepted: January 16, 2021; Published: February 9, 2021

\begin{abstract}
Environmental challenges and high cost of fossil fuel has made Biodiesel gained more recognition as alternative fuel. In this study, heterogeneous catalyst was developed via dealumination of Ukpor clay and calcined snail shells. Basicity, morphology, textural characteristics among other properties of catalyst were studied using XRF, FTIR, SEM, XRD, EDS, BET, XPS and TGA analyses. The optimization of Moringa Oleifera seed oil biodiesel production was carried out via Central Composite Rotatable Design matrix (CCRD) and Response Surface Methodology (RMS). The variables investigated were temperature, time, catalyst concentration and agitation speed. Biodiesel samples were separated from reactant and impurities via decantation and distillation processes. At a combination of $240 \mathrm{~min}, 300^{\circ} \mathrm{C}, 4.0 \mathrm{wt} \%$, and $300 \mathrm{rpm}$ of time, temperature, catalyst concentration and agitation speed, the maximum yield of $45.50 \%$ was obtained. The FTIR, GC-MS and characteristics of the biodiesel produced conform to ASTM standards. The statistical model developed for the effects and percentage contributions of the optimization variables is in the form of; Yield $=+25.85+5.88 * \mathrm{~A}+3.19 * \mathrm{~B}-2.60 * \mathrm{C}+0.71 * \mathrm{D}+2.29 * \mathrm{~A} * \mathrm{~B}+1.67 * \mathrm{~A} * \mathrm{C}-$ $0.069 * A * D+2.54 * B * C+0.66 * B * D-2.27 * C * D+0.14 * A 2+2.12 * B^{2}+1.49 * C^{2}-0.78 * D^{2}$ while the reaction obeys first order kinetics, the reaction proceeds faster at elevated temperatures. The calculated activation $\left(\mathrm{E}_{\mathrm{a}}\right)$ recorded is $2.94 \mathrm{kJmol}^{-1} \mathrm{~K}^{-1}$.
\end{abstract}

Keywords: ANOVA, Heterogeneous, Transesterification, Optimization, Moringa Oleifera

\section{Introduction}

Biodiesel is obtainable from the transesterification of vegetable oils and fats. Some of the merits associated with this nontoxic, renewable and biodegradable fuel source cut across zero sulphur contents, higher cetane number, higher heating value (flash point) and lower emission of SOx, NOx among other carcinogenic compounds [1]. Biodiesel is often regarded as "green alternative" fuel resource [2]. Generally, major hindrances associated with large scale production and availability of biodiesel are insufficiency of feed stocks, higher cost of production. Nonedible and zero cost feed stocks such as jatropha oil and waste cooking oils are said to be feasible economic alternatives capable of improving large scale biodiesel production on a global scale. Despite the overwhelming potentials and advantages associated with adoption of renewable energy sources as possible replacement to petroleum, especially as it pertains to biodiesel production from vegetable oil, there are areas of concerns. The ever present demand for food security and sustainability is always a competing demand that needs to be appropriately weighed before industrial or large scale utilization of food crops for energy production is contemplated. However, the use of edible feed such as moringa oleifera seed oil is associated with huge and advantages in terms of rural revitalization, job creation, curbing the menace of rural-urban migration as well as reduction in global warming amongst others [3]. Moreover, homogeneous catalysts that are either acidic or basic employed in the transesterification of fats and vegetable oils for biodiesel production are associated with high rates of conversion and/or output [4]. On the contrary, difficulty in products separation, 
corrosion tendencies, development of emulsions, tediousness in removing the catalyst used and its subsequent disposal are some the demerits associated with the use of homogeneous catalysts whether acidic or basic in the synthesis of biodiesel. To overriding the demerits associated with the use of homogeneous catalysts, the development and application of heterogeneous catalysts has become imperative [5]. Interest on $\mathrm{CaO}$ and $\mathrm{MgO}$ (alkaline earth oxides) oriented heterogeneous catalysts have been on the relative to others due to dissolution and solubility tendencies of other mediums $[6,7]$ transesterified tributyrin and methanol over $\mathrm{CaO}$ catalysts developed using different precursors such as Calcium Acetate Monohydrate (CA), Calcium Carbonate (CC), Calcium Hydroxide $(\mathrm{CH})$, Calcium Nitrate Tetrahydrate $(\mathrm{CN})$ and Calcium Oxalate Monohydrate (CO) calcined between 500 at $100^{\circ} \mathrm{C}$ for a maximum of $2 \mathrm{hrs}$. $\mathrm{CN}-800<\mathrm{CC}-800<\mathrm{CO}-800 \approx$ CA-800 $<$ CH-800 was the observed catalytic activities with rate of conversion over $\mathrm{CH}-800$ at mole ratio of 1:6 and weight percentage of 16.40:0.010 for tributyrin-methanol and reactant-catalyst mass respectively. Basicity of $\mathrm{CaO}$ catalysts developed were observed to be different according to precursors thereby giving room for establishing that the relationship between the rates of conversion and the basicity of the $\mathrm{CH}$ catalysts developed. [8], probed $\mathrm{CaO}$ based catalyst developed from pulverized lime stone at a calcination temperature and conversion time of $900^{\circ} \mathrm{C}$ and $1.50 \mathrm{hrs}$ in the transesterification of soybean oil to produce biodiesel. $\mathrm{CaO}>\mathrm{Ca}(\mathrm{OH}) 2>\mathrm{CaCO} 3$ was the observed catalytic activity sequence of the production process an optimal yield of $93.00 \%$ for $\mathrm{CaO}$ followed by $12.00 \%$ for $\mathrm{Ca}(\mathrm{OH})_{2}$ and $0.00 \%$ for $\mathrm{CaCO}$. Basicity was established as the major determining factor for the catalytic activities of the samples under study. In this research work, kaolinite clay (Ukpor clay) and snail shells were synthesized and applied in the production of biodiesel from Moringa Oleifera seed oil. Characterization of the raw materials and doped catalyst were done through XRF, FTIR, SEM, XRD, EDS, BET, XPS and TGA to enable understanding of their molecular structures, compounds of interest, porosity, grain sizes, elemental proportions, surface areas, IR spectra and weight losses and morphologies.

\section{Materials and Methods}

\subsection{Materials}

Moringa Oleifera seed oil used in the study was purchased from Dorayi, a local market in Kano State, Nigeria was characterized by Ameh, [9]. The snail shells used were purchased from Kasuwan Gwari, Minna, Niger State, Nigeria and the Ukpor clay was collected from Ukpor in Anambra State, Nigeria. The chemicals and reagents used in this study were of analytical grade purchased from Steve Moore Chemicals, Zaria, Kaduna State, Nigeria which includes sulphuric acid, ammonium sulphate, and ethanol.

\subsection{Methods}

\subsubsection{Preparation of Heterogeneous Catalysts}

Dealumination of Ukpor clay was according to Eterigho, [10]. A known weight of uncalcined clay was mixed with a standard analytical-grade $36 \mathrm{~N}$ sulphuric acid $\left(\mathrm{H}_{2} \mathrm{SO}_{4}\right)$ solution a molar ratio of 1: 5. Aliquot of the mixture was placed in open quartz crucible, which was heated in a furnace at $500^{\circ} \mathrm{C}$, ramped at $5^{\circ} \mathrm{C} \mathrm{min}^{-1}$ for $1 \mathrm{hr}$. Once the reaction temperature was reached the crucible was left in the furnace for another $6 \mathrm{hrs}$.

\subsubsection{Preparation Snail Shells}

The shells were each washed thoroughly with distilled water to remove dirt. Thereafter, the samples were sun-dried for a maximum of five (5) days. After the attainment of a constant drying weight, the samples were then calcined using a furnace. Each sample was calcined at $1000^{\circ} \mathrm{C}$ for $2 \mathrm{hrs}$. The calcined samples were left to cool at room temperature before grinding each sample into powder form using laboratory ball mills. Finally, the samples were sieved using 75 microns' sieve size and stored in air tight containers [11].

\subsubsection{Doping of Sulphated Snail Shells}

In order to activate the silica for the reactions involved in the study, it has been found necessary to convert the kaolin into metakaolin by thermal treatment [10]. The resultant metakaolin was doped with snail shell before sulphating the samples with ammonium sulphate $\left(\mathrm{NH}_{4}\right)_{2} \mathrm{SO}_{4}$ [9-10].

\subsection{Characterization of Doped Snail Shell Catalyst}

The doped catalyst was characterized by X-ray diffraction (XRDP) powder patterns, Infrared (IR) spectroscopy, Scanning Electron Microscopy (SEM), X-ray photoelectron spectroscopy (XPS), Energy Dispersive X-ray (EDX), Fourier Transform Infrared Spectroscopy (FT-IR) Thermogravimetric Analysis (TGA) and Brunauer-Emmett-Teller (BET) nitrogen desorption measurements for the surface areas $[9,10]$.

\subsection{Composition Analysis of the Produced Biodiesel}

Fourier Transform Infrared spectroscopy (FT-IR) Agilent Technologies was used to analyze samples of the biodiesel produced from snail shell catalysts. Sixteen (16) background scans involving eight (8) resolutions were taken and the samples were recorded in the range of 4000 to $650 \mathrm{~cm}^{-1}$ [9].

\subsection{Gas Chromatography Mass Spectrometry (GC-MS)}

The biodiesel samples produced from snail shells were analyzed by means of PerkinElmer Clarus 500 Gas Chromatograph couplet to Clarus 500 Mass Spectrometer with liquid automatic sampler using helium as the vector gas under 30 $\mathrm{m}, 0.25 \mu \mathrm{m}$ and $2 \mu \mathrm{l}$ for height of capillary column, capillary column diameter and sample injection rate respectively. Initially, the temperature was held at $50^{\circ} \mathrm{C}$ for $3 \mathrm{~min}$. Thereafter, $280^{\circ} \mathrm{C}$ at an increment rate of $10^{\circ} \mathrm{C} \mathrm{min}^{-1}$ and for $3 \mathrm{~min}$ [12].

\section{Results and Discussion}

\subsection{Analyses of the Catalyst Composition}

\subsubsection{XRF}

XRF analysis was carried out on the locally abundant raw materials, that is, kaolin (Ukpor clay), meta-kaolin, snail shells 
and the corresponding heterogeneous catalysts produced. The XRF analysis presented in Table 1, show that the compounds of interest $\left(\mathrm{SiO}_{2} / \mathrm{Al}_{2} \mathrm{O}_{3}\right)$ are in a ratio of 2:7. After the dealumination, the alumina and the silica were reduced by $83 \%$ and 74.72 respectively. While, oxygen levels in both stages remained relatively constant. $0.00 \mathrm{wt} \%$ sulphur oxide was and $0.2942 \mathrm{wt} \%$ of the oxides of sulphur were recorded in the kaolin (Ukpor clay) and dealuminated clay (meta-kaolin) respectively. This phenomenon is attributed to the use of sulphuric acid $\left(\mathrm{H}_{2} \mathrm{SO}_{4}\right)$ during the dealumination process. The dealumination is said to be a success due to the fact that $\mathrm{SiO}_{2} / \mathrm{Al}_{2} \mathrm{O}_{3}$ ratio of the kaolin, which was initially 2:7 has increased to 11.2. Hence, the dealuminated clay is said modified to have more of silica and less of alumina relative to the kaolin in its natural state. The results obtained are in agreement with the work of Eterigho 2011, [10], who reported $86 \%$ and $74 \%$ reduction of alumina and silica oxides and $0.90 \%$ sulphur content on the same material (Ukpor clay). However, the slight differences observed are attributed to morphological variations of the samples used.

Table 1. Compositions of Ukpor Clay (Kaolin) and Meta-Kaolin.

\begin{tabular}{|c|c|c|c|}
\hline \multirow{2}{*}{$\mathbf{S} / \mathbf{N}$} & \multirow{2}{*}{ Compounds } & \multirow{2}{*}{$\begin{array}{l}\text { Samples } \\
\mathrm{K}\end{array}$} & \multirow{2}{*}{$\begin{array}{l}\text { Compositions (\%) } \\
\text { M }\end{array}$} \\
\hline & & & \\
\hline 1 & $\mathrm{Fe}_{2} \mathrm{O}_{3}$ & 1.96 & 1.52 \\
\hline 2 & $\mathrm{Mn}_{2} \mathrm{O}_{3}$ & 0.01 & 0.05 \\
\hline 3 & $\mathrm{Cr}_{2} \mathrm{O}_{3}$ & 0.01 & 0.06 \\
\hline 4 & $\mathrm{~V}_{2} \mathrm{O}_{5}$ & 0.02 & 0.00 \\
\hline 5 & $\mathrm{TiO}_{2}$ & 2.28 & 1.51 \\
\hline 6 & $\mathrm{CaO}$ & 0.07 & 0.23 \\
\hline 7 & $\mathrm{~K}_{2} \mathrm{O}$ & 0.05 & 0.02 \\
\hline 8 & $\mathrm{P}_{2} \mathrm{O}_{5}$ & 0.06 & 0.62 \\
\hline 9 & $\mathrm{SiO}_{2}$ & 70.71 & 55.12 \\
\hline 10 & $\mathrm{Al}_{2} \mathrm{O}_{3}$ & 17.16 & 10.32 \\
\hline 11 & $\mathrm{MgO}$ & 0.05 & 0.37 \\
\hline 12 & $\mathrm{Na}_{2} \mathrm{O}$ & 0.01 & 0.77 \\
\hline 13 & $\mathrm{ZnO}$ & 0.03 & 0.00 \\
\hline 14 & $\mathrm{SrO}$ & 0.92 & 0.01 \\
\hline 15 & $\mathrm{Cl}$ & 0.00 & 0.01 \\
\hline \multirow[t]{2}{*}{16} & $\mathrm{SO}_{3}$ & 0.00 & 29.42 \\
\hline & Total & 100.00 & 100.00 \\
\hline
\end{tabular}

Where:

$\mathrm{K}=$ Kaolin

$\mathrm{M}=$ Meta-kaolin

On the other hand, the XRF analysis of snail shells depicts that the elements and compounds of interest $\left(\mathrm{Al}, \mathrm{Si}\right.$ and $\mathrm{SiO}_{3} /$ $\mathrm{Al}_{2} \mathrm{O}_{3}$ ) are in a ratio of 1:6:4. Table 2 depicts the compositions of snail shells before and after calcination at $1000^{\circ} \mathrm{C}$ for $2 \mathrm{hrs}$ respectively. It can be seen from Table that $\mathrm{Al}, \mathrm{Si}, \mathrm{CaO}$ and $\mathrm{SO}_{3}$, recorded increase of $6 \%, 36 \%, 21 \%$ and $6 \%$ for snail shells before and after calcination. It is deduced that heating the sample (snail shells) until its temperature is high, but still below its melting point, is mainly to eliminate element and/or compounds that can evaporate often release water, increase their crystallinities while at the same time improve their specific properties-pore size. Hence, there exist increments in the value of $\mathrm{CaO}$ after calcination. It is deduced that the both parameters (time and calcination temperature) are significant parameters in the study. This result is in agreement with the findings of Natthanicha and Siriwan, 2017; Widayat et al.
2013, [13-15], who observed increments in the value of $\mathrm{CaO}$ of Ukpor clay and Limestone at different calcination time and temperature.

Table 2. Compositions of Snail Shells.

\begin{tabular}{|c|c|c|c|}
\hline \multirow{2}{*}{$\mathbf{S} / \mathbf{N}$} & \multirow{2}{*}{ Elements and Compounds } & \multicolumn{2}{|c|}{ Compositions (\%) } \\
\hline & & $\mathbf{S}_{1}$ & $\mathbf{S}_{2}$ \\
\hline 1 & $\mathrm{Na}$ & 1.50 & 1.72 \\
\hline 2 & $\mathrm{Mg}$ & 0.43 & 0.61 \\
\hline 3 & $\mathrm{Al}$ & 2.74 & 2.91 \\
\hline 4 & $\mathrm{Si}$ & 15.11 & 17.87 \\
\hline 5 & $\mathrm{P}$ & 0.98 & 0.81 \\
\hline 6 & $\mathrm{SO}_{3}$ & 59.98 & 63.71 \\
\hline 7 & $\mathrm{Cl}$ & 0.29 & 0.08 \\
\hline 8 & $\mathrm{~K}_{2} \mathrm{O}$ & 0.22 & 0.05 \\
\hline 9 & $\mathrm{CaO}$ & 9.33 & 11.73 \\
\hline 10 & $\mathrm{TiO}_{2}$ & 1.28 & 0.27 \\
\hline 11 & $\mathrm{Cr}_{2} \mathrm{O}_{3}$ & 1.71 & 0.01 \\
\hline 12 & $\mathrm{Mn}_{2} \mathrm{O}_{3}$ & 0.02 & 0.01 \\
\hline 13 & $\mathrm{Fe}_{2} \mathrm{O}_{3}$ & 2.40 & 0.33 \\
\hline 14 & $\mathrm{ZnO}$ & 2.70 & 0.00 \\
\hline \multirow[t]{2}{*}{15} & $\mathrm{SrO}$ & 1.37 & 0.00 \\
\hline & Total & 100.00 & 100.00 \\
\hline
\end{tabular}

Where:

$\mathrm{S}_{1}$ and $\mathrm{S}_{2}=$ Raw Snail Shells and Calcined Snail Shells

\subsubsection{FT-IR}

The FTIR spectra of the heterogeneous catalysts as shown in Figure 1 depicts highly significant broad bands at approximately $3205 \mathrm{~cm}^{-1}$. representing the hydroxyl groups $(\mathrm{OH})$ stretching vibrations of the hydroxyl groups in the brucite-like sheets [16]. This phenomenon is attributed to the total dehydration and calcination of the samples, thereby demonstrating lack of water quantities. On the other hand, spectra within the range of $800-1000 \mathrm{~cm}^{-1}$ are said to be the stretching modes of oxides in the brucite-like layers whereas the $712 \mathrm{~cm}^{-1}$ for snail shells depict the presence of $\mathrm{OH}$ groups as a result of cations of alumina [17]. The spectra bands in the range of $600 \mathrm{~cm}^{-1}$ portrayed by the catalyst is a summary representation of magnesium hydroxide $(\mathrm{Mg}-\mathrm{OH})$ stretch modes. $1075^{-1}$ observed in snail shells $\mathrm{CaO}$ based heterogeneous catalyst signifies the $\mathrm{OH}$ deformities modes. The absorption peaks at approximately $3205 \mathrm{~cm}^{-1}$ confirms the presence of the availability of many different bonded oxides of Fe, Mn, Cr, V, Ti, K, P, Al, Na and S [18].

\subsubsection{SEM}

Figure 2a-b depict the surface analysis (SEM) of the Ukpor clay and the meta-kaolin using $5.00 \mathrm{Kv}, 100-200 \mathrm{~nm}$ and at magnifying powers of $20 \mathrm{KX}$. The results obtained on kaolin and meta-kaolin have shown that the kaolin has larger porosity compared to the later while at the same time also depicting structural non-aggregations of the materials. The pore diameter obtained for raw kaolin is larger. Figure 2a-b depicts the SEM analysis for snail shells catalyst. The larger the pore size of catalysts, the easier the absorption of fat or impurity fat due to the ability of the fat to pass through the structure and vice-versa [19]. The structural porosity increase in natural materials (limestone and clay) is tantamount to increasing the yield of biodiesel [20]. The biodiesel produced from this 
material will require high steps of washing which will ultimately affect the yield.

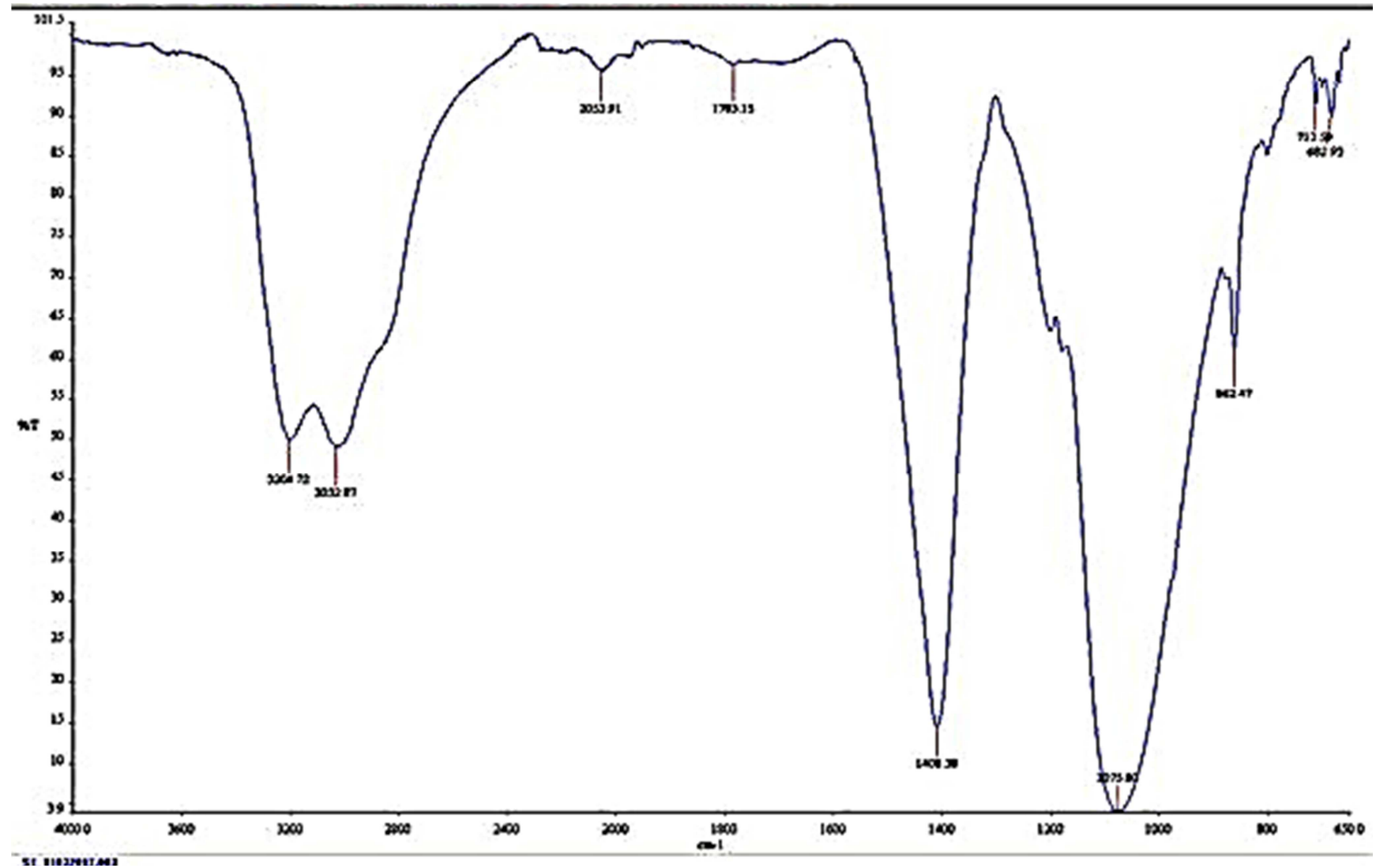

Figure 1. FTIR Analysis of CaO based Heterogeneous Catalyst Developed from Snail Shells.

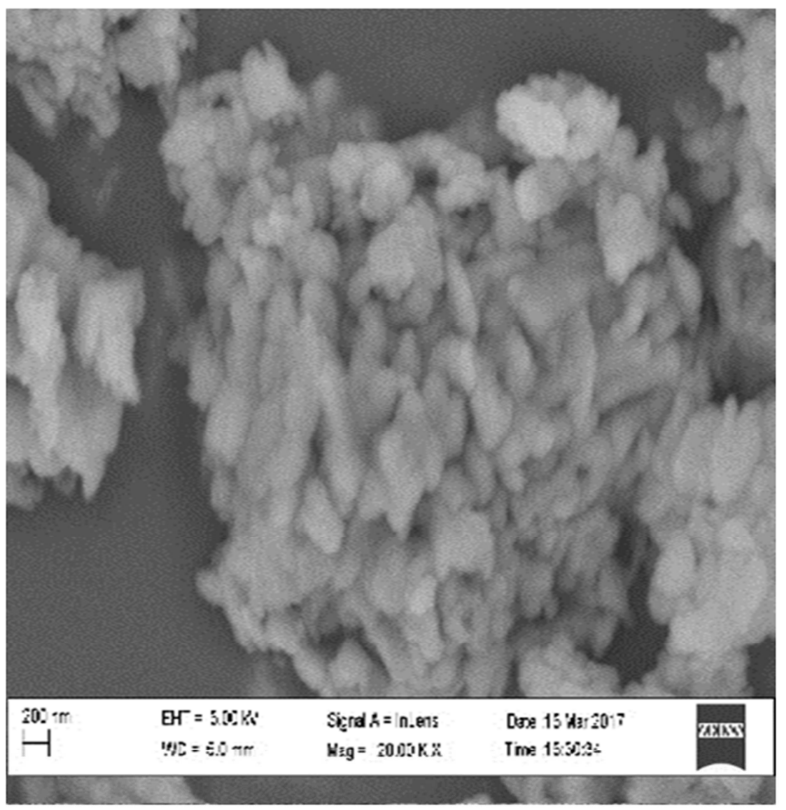

(a)

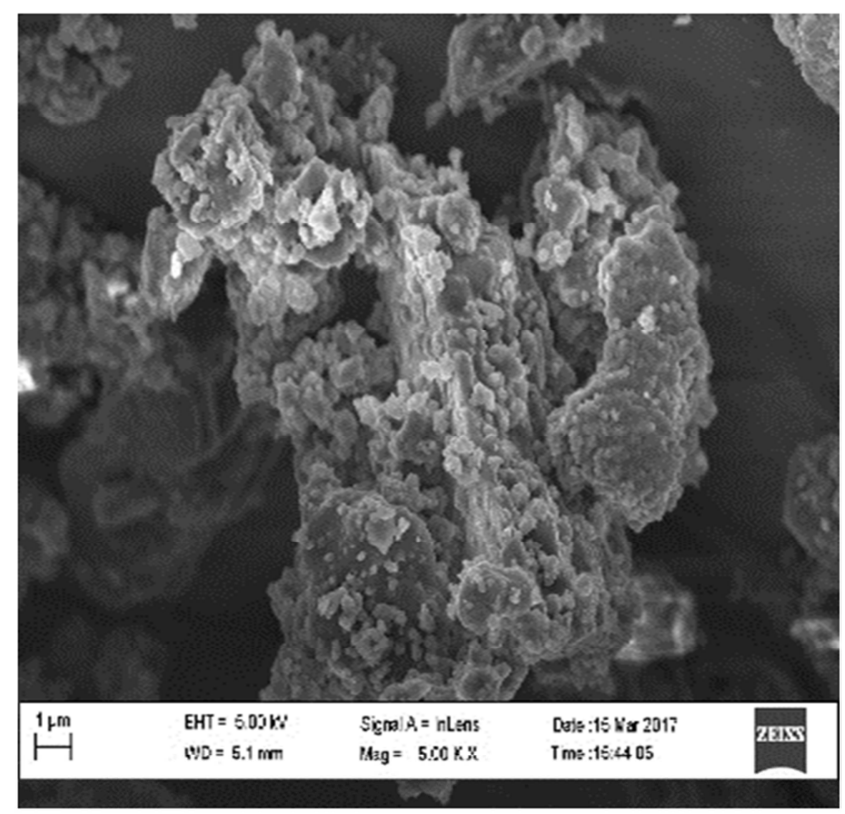

(b)

Figure 2. SEM Analysis for; (a) Metakaolin; (b) CaO based Catalyst from Snail Shells.

\subsection{4. $X R D$}

$\mathrm{X}$-ray diffraction is employed in the estimation of the average crystallites or grain sizes of catalysts [19]. The XRD analyses were carried out on the kaolin, meta-kaolin and the
$\mathrm{CaO}$ based heterogeneous catalyst developed from snail shells mainly to derive structural information of the catalysts produced. Figures 3-5 depict the XRD patterns of kaolin (Ukpor clay), meta-kaolin and heterogeneous catalyst 
developed from snail shells. Due to the fact that the sample is in the form of polycrystalline powder, the XRD analyses is therefore geared towards the identification of specific lattice planes that produce peaks at their corresponding angular positions $2 \theta$, determined by Bragg's law $[10,21]$. However, the XRD pattern obtained from Ukpor clay (kaolin) was crystalline in nature with three (3) phases identified mainly as kaolinite and traces of quartz and mica. The XRD pattern obtained is in line with the pattern obtained by [10]. Similarly, the XRD pattern of meta-kaolin depicts less peaks of kaolinite crystalline. According to Eterigho 2011, [10], the$$
\text { (10) }
$$

Figure 3. XRD Analysis for Ukpor Clay.

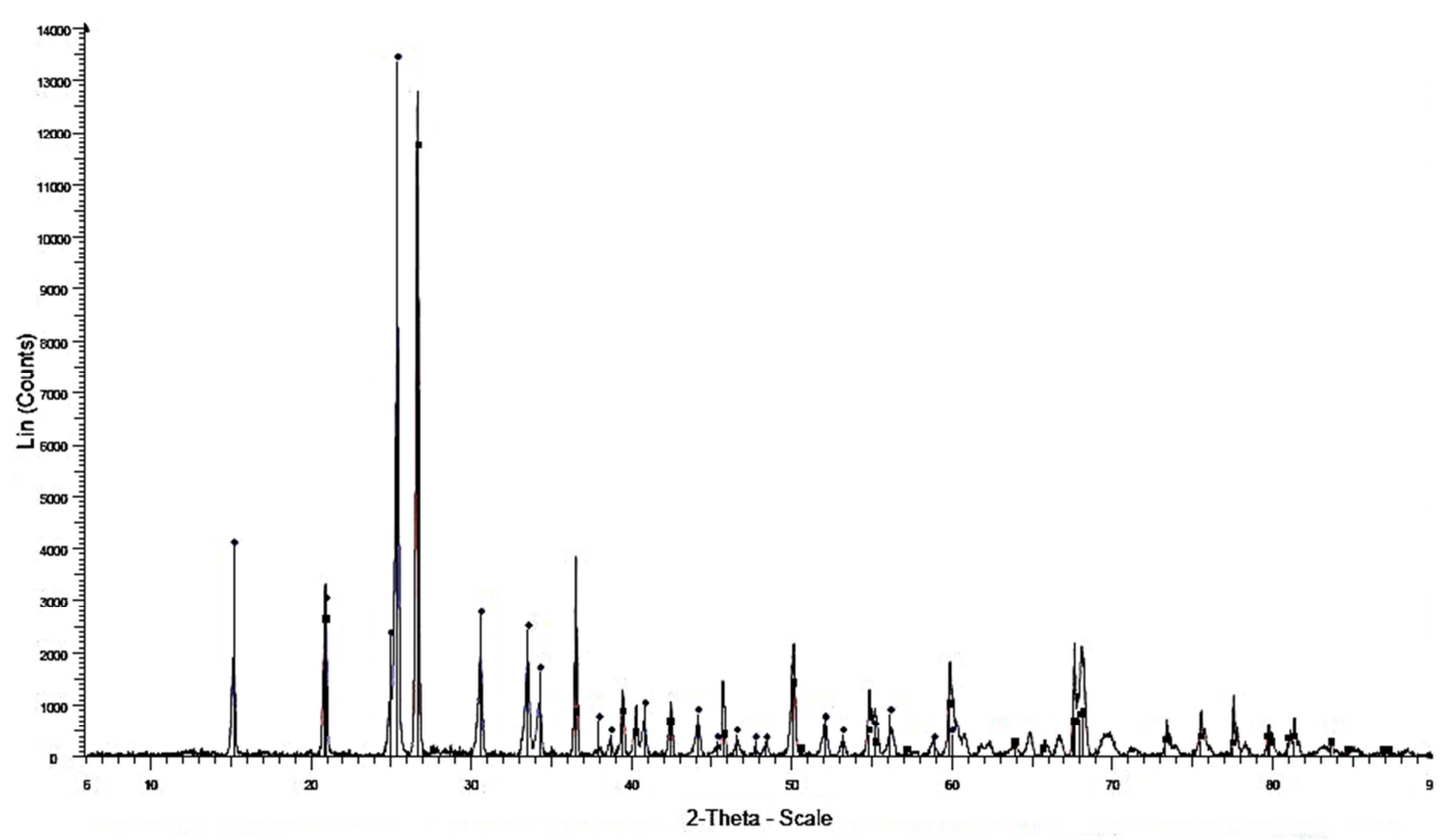

Figure 4. XRD Analysis for Metakaolin. material with a very broad band within the low-range angle 15 - $35^{\circ}$ and such broad bands are said to be amorphous phase of silica $\left(\mathrm{SiO}_{2}\right)$. Moreover, the interaction of snail shells indicates that hydroxyl groups of sodium $(\mathrm{Na})$ have reacted with the support of $\mathrm{Al}_{2} \mathrm{O}_{3}$ giving rise to the formation of alumina that originated the stronger basic sites of the catalyst [22]. Hence, the XRD peaks obtained from the heterogeneous catalyst is said to be intense and sharp because they have sufficient long-range order, thereby becoming broader for crystallite sizes below about $100 \mathrm{~nm}$ [23]. 


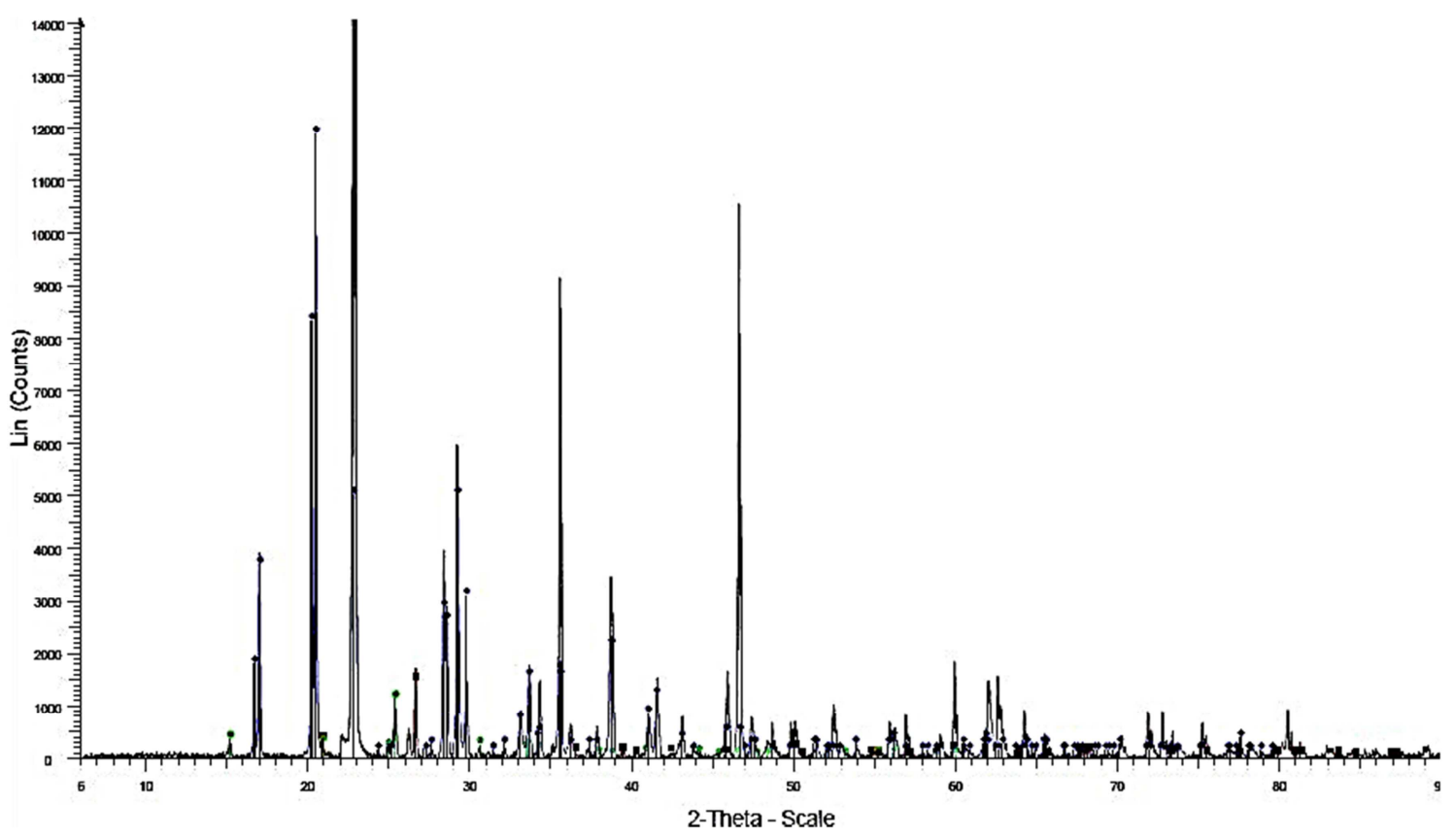

Figure 5. XRD Analysis for CaO based Heterogeneous Catalyst from Snail Shells.

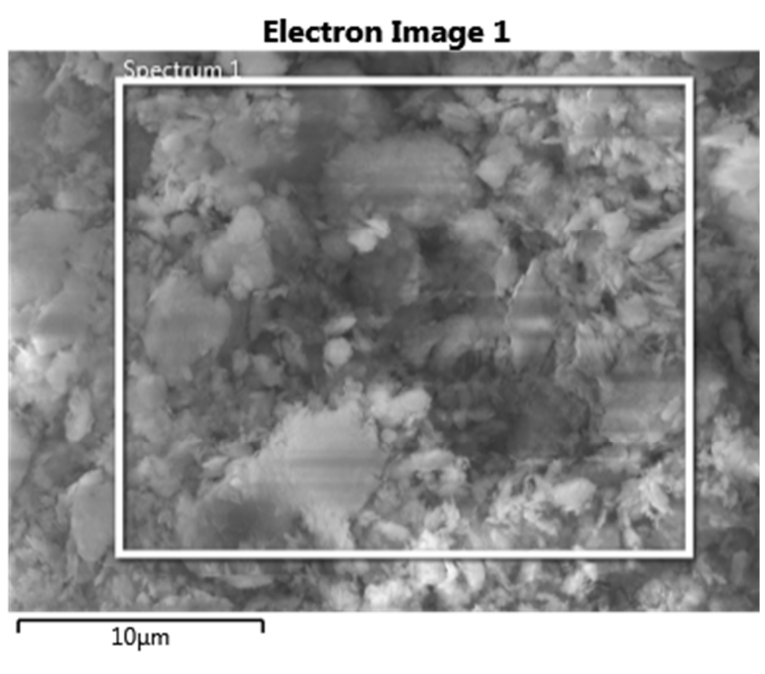

Figure 6. EDS Analysis for Ukpor Clay.

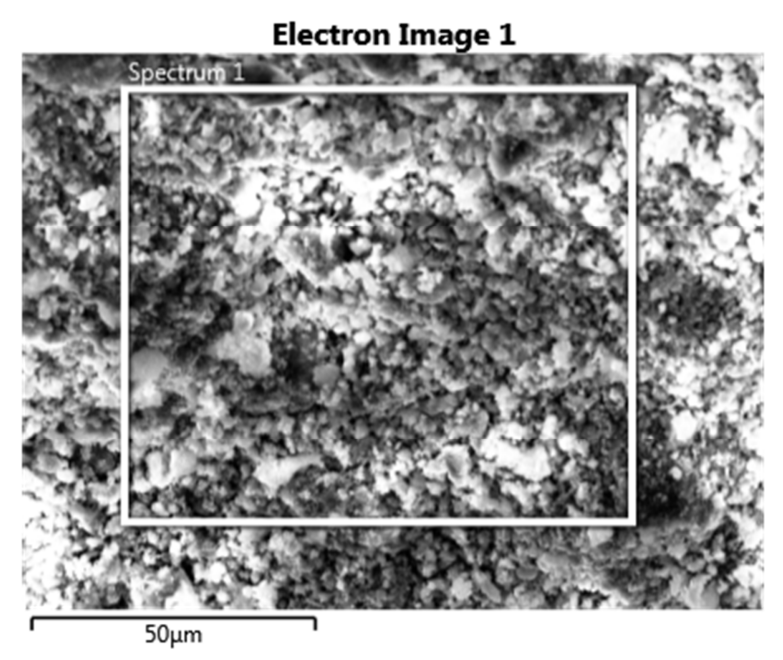

Figure 7. EDS Analysis for Metakaolin.

\subsubsection{EDS}

Energy-dispersive X-ray spectroscopy (EDS) coupled with SEM measurement was carried out on kaolin, meta-kaolin and the $\mathrm{CaO}$ based heterogeneous catalyst developed from snail shells mainly for the determination of the mean elements proportions of the samples and the level of homogeneity of the catalysts developed. Interestingly, the chemical and elemental compositions of the kaolin, meta-kaolin and the heterogeneous catalyst developed and analyzed via EDS were quite similar to what was obtained in the XRF analysis reported in literature, $[10,24]$. Figures 6 - 8 depict the EDS images of Ukpor clay, meta-kaolin and the heterogeneous catalyst developed from snail shells respectively.

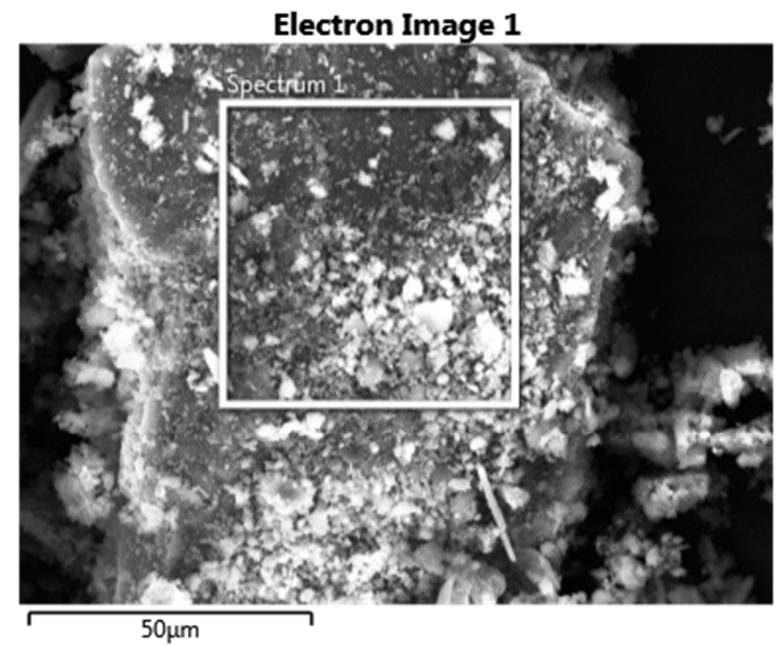

Figure 8. EDS Analysis for CaO based Heterogeneous Catalyst from Snail Shells.

\subsubsection{BET}

The BET analyses for the kaolin, meta-kaolin and heterogeneous catalyst developed were carried out using 
NOVA STATION D instrument at $0.25 \mathrm{~g}$, weight; $3 \mathrm{hrs,} \mathrm{out}$ gas time; nitrogen, analysis gas; 0.100 , precision tolerance; $6,054 \mathrm{sec}$, analysis time; $250^{\circ} \mathrm{C}$, out gas temperature and $273^{\circ} \mathrm{K}$, bath time. The surface areas recorded were 196.468 $\mathrm{m}^{2} \mathrm{~g}^{-1}, \quad 180.709 \mathrm{~m}^{2} \mathrm{~g}^{-1}$ and $199.662 \mathrm{~m}^{2} \mathrm{~g}^{-1}$ for kaolin, meta-kaolin and $\mathrm{CaO}$ based heterogeneous catalyst developed from snail shells respectively. This phenomenon can be attributed to the collapse of the surface area during the second calcination due to fortification of meta-kaolin with snail shells [25]. Table 3 show summary of the BET analysis results for the kaolin, meta-kaolin and the $\mathrm{CaO}$ based heterogeneous catalyst developed while Figures 9-11 shows the BET results for kaolin, meta-kaolin, snail shells $\mathrm{CaO}$ based heterogeneous catalyst developed.

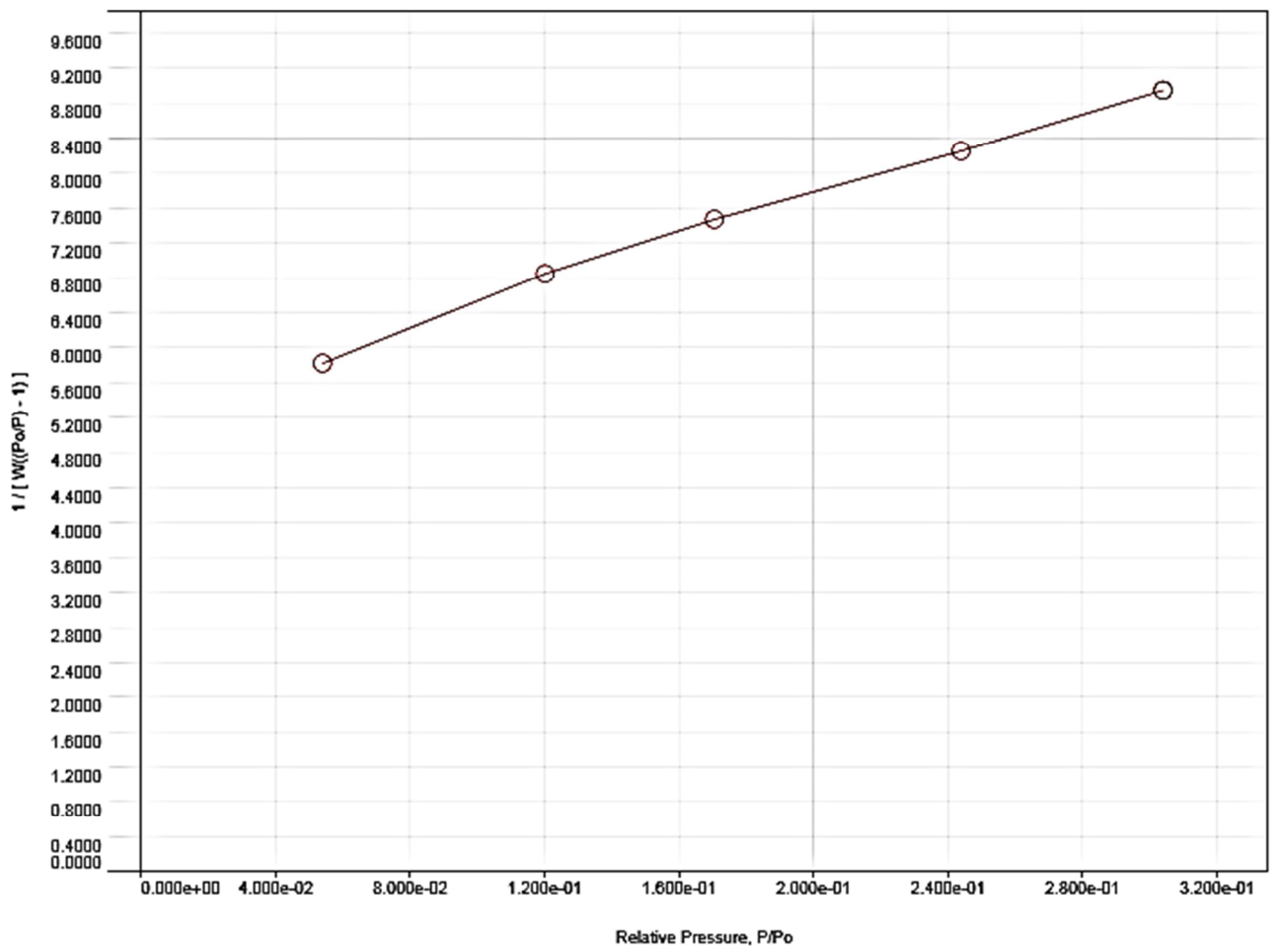

Figure 9. BET Analysis for Ukpor Clay.

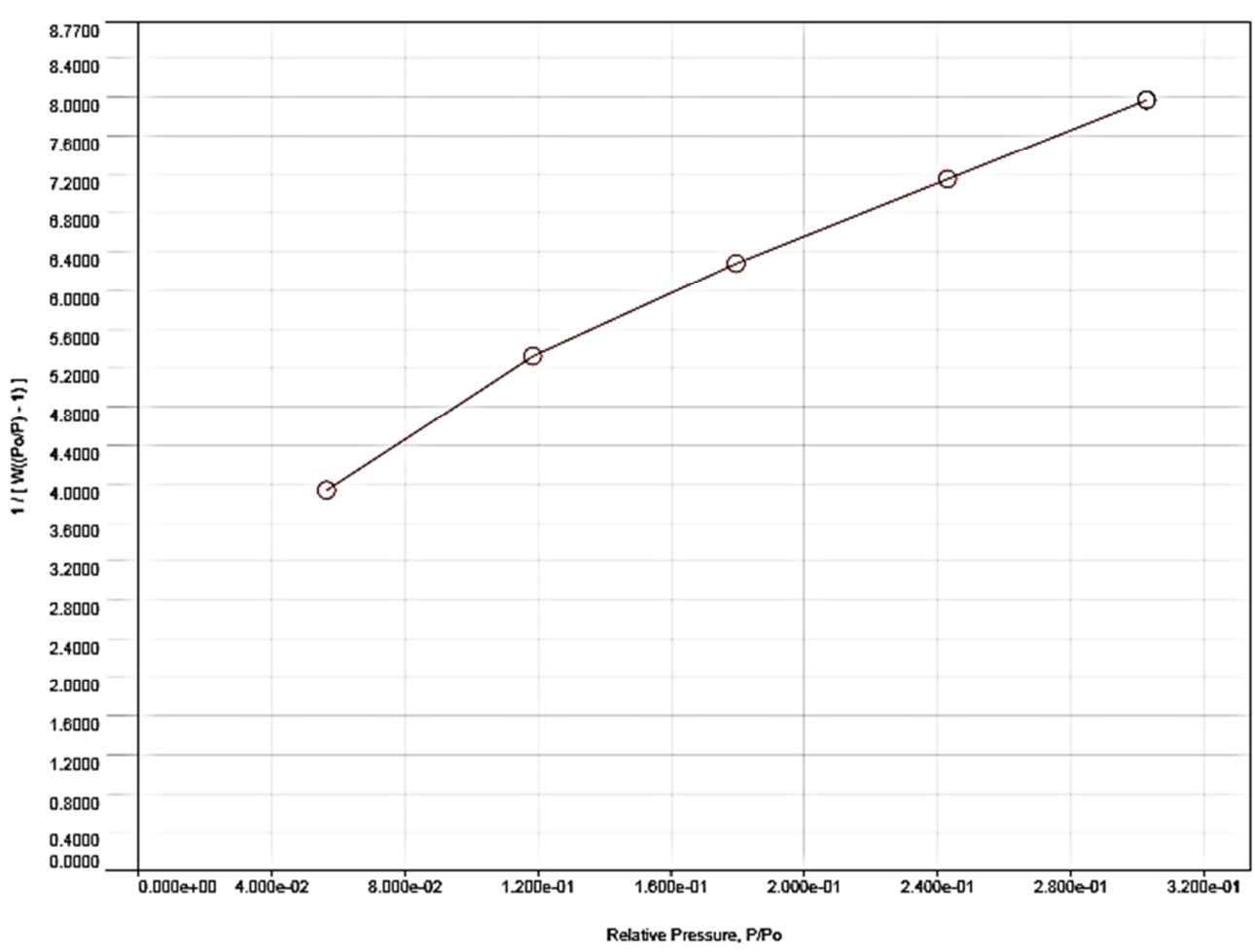

Figure 10. BET Analysis for Metakaolin. 


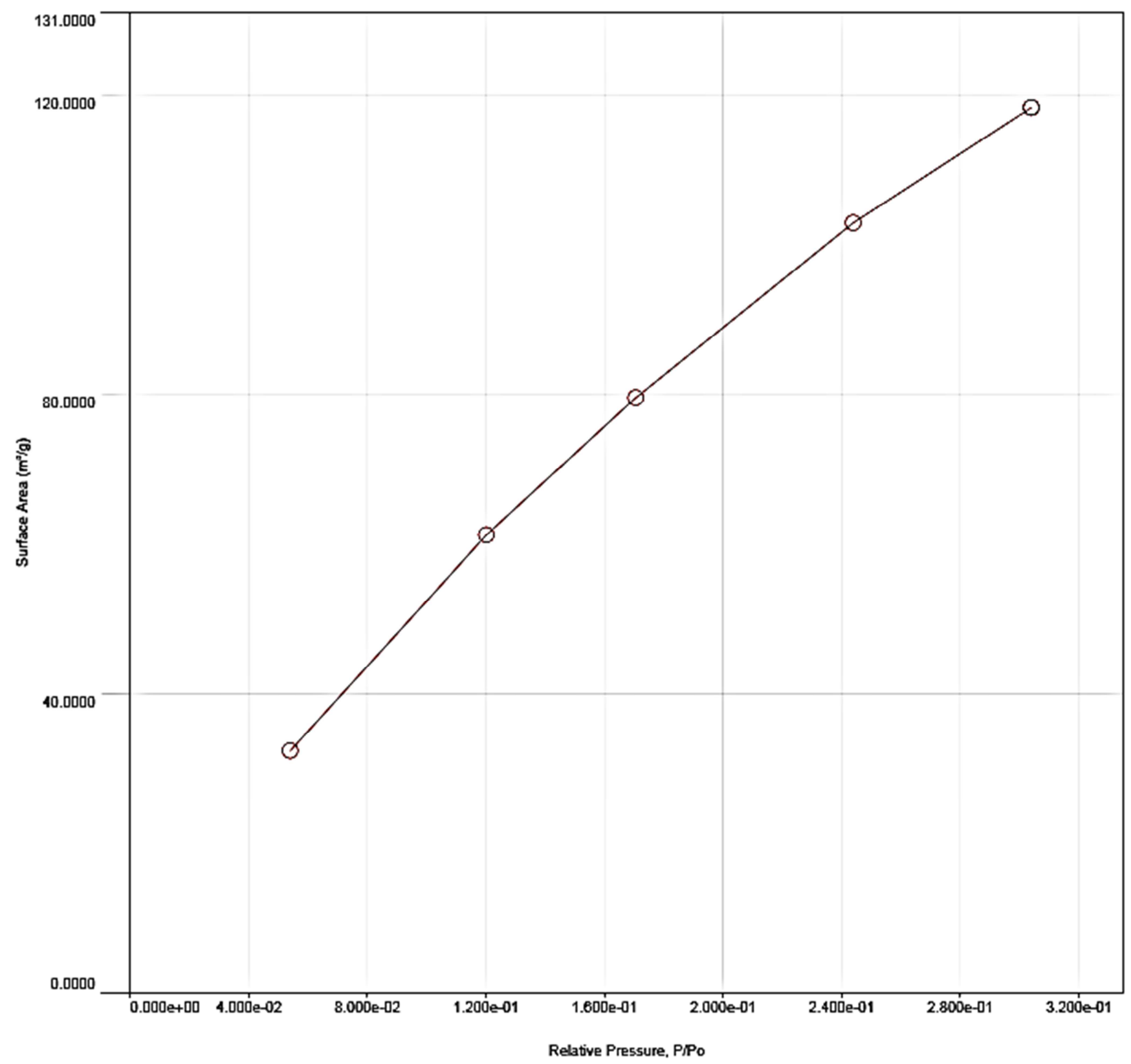

Figure 11. BET Analysis for CaO based Heterogeneous Catalyst from Snail Shells.

Table 3. Summary of BET Analysis Results for Kaolin, Meta-kaolin and Snail Shells CaO based Heterogeneous Catalyst.

\begin{tabular}{lllll}
\hline S/N & Properties & K & Samples M & S \\
\hline 1 & Slope & 12.2710 & 16.0260 & 12.4260 \\
2 & Intercept & 5.2760 & 3.2460 & 5.0160 \\
3 & Correlation Coefficient & 0.9968 & 0.9939 & 0.9989 \\
4 & Surface Area $\left(\mathrm{m}^{2} \mathrm{~g}^{-1}\right)$ & 196.468 & 180.7090 & 199.6610 \\
\hline
\end{tabular}

Where:

$\mathrm{K}=$ Kaolin

$\mathrm{M}=$ Meta-kaolin

$\mathrm{S}=$ Snail Shells Heterogeneous Catalyst

\subsubsection{XPS}

The XPS analysis for the catalyst sample was carried out at a take-off angle, pass energy, scan rate, analyses area and a pressure of $45^{\circ} \mathrm{C}, 178.95 \mathrm{eV}, 2.5 \mathrm{eVs}^{-1}, 3^{*} 10 \mathrm{~mm}^{2}$ and $<$ $5^{*} 10^{-9}$ Torr respectively. The effect of dealuminating kaolin on ratio composition (ratio) of silica to alumina ( $\mathrm{Si} / \mathrm{Al}$ ) ratio is also depicted by XPS analysis on the heterogeneous catalysts developed. The Al $2 p$ spectra for all the samples at the same binding energy correspond to aluminum (III) oxide. Also, the silicon ( $\mathrm{Si} 2 \mathrm{p})$ spectrum of the sample is very similar around 
$100 \mathrm{eV}$. Similarly, literature reported $103.30 \mathrm{eV}$ (the binding energy of silicon), which indicated that it was $\mathrm{Si}_{4}+$ in silicon oxide [10]. This little variation in the pass energy is attributed to the doping of snail shells powder to the meta-kaolin samples. Figure 12 represents the XPS analysis of the $\mathrm{CaO}$ based heterogeneous catalyst developed from snail shells.

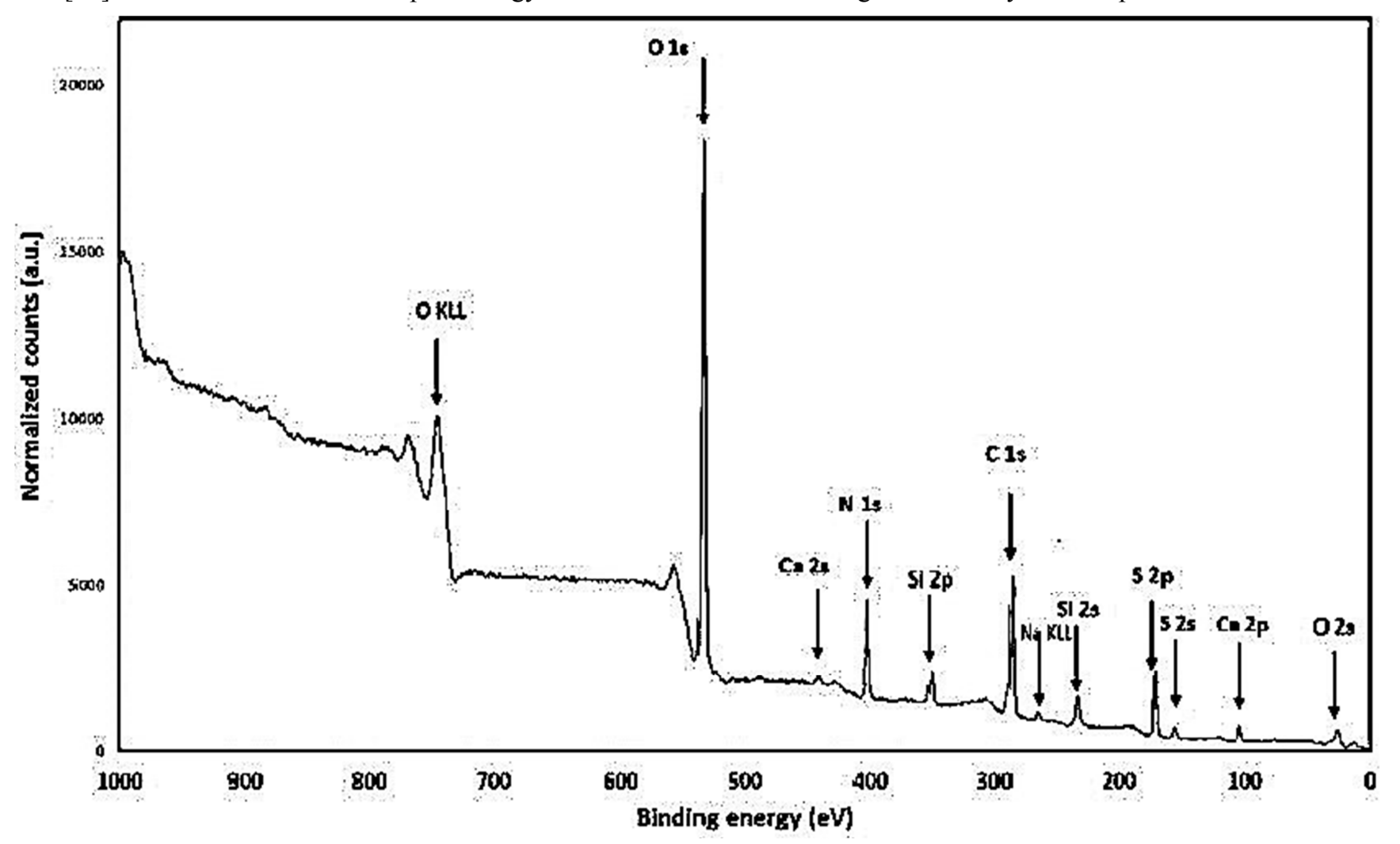

Figure 12. XPS Analysis for CaO based Heterogeneous Catalyst from.

\subsection{8. $T G A$}

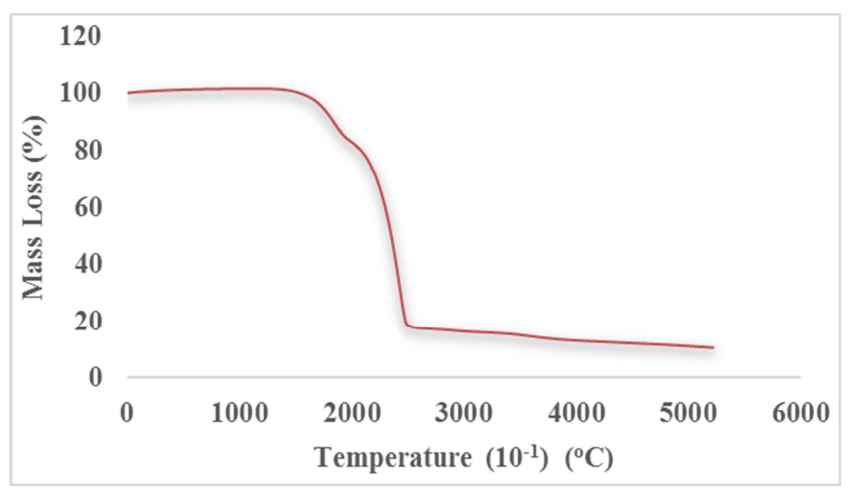

Figure 13. TGA Analysis for CaO based Heterogeneous Catalyst from.

The TGA curve features two major peaks in which one is endothermic while the second is exothermic for the sample. From the TGA plot of the $\mathrm{CaO}$ based heterogeneous catalyst developed from snail shells shown in Figure 13, it can be seen that the first endothermic peak appears at lower temperature $\left(250^{\circ} \mathrm{C}\right)$. This phenomenon (weight loss) can be attributed to the de-adsorption of humidity on the exterior surface of the samples; residual water can be desorbed from the surface during heating the sample by the TG analyzer [26, 27]. The second stage occurs at about $250^{\circ} \mathrm{C}-600^{\circ} \mathrm{C}$ (exothermic peak) at about $2500^{\circ} \mathrm{C}$ may be attributed to the crystallization of amorphous compounds therein [28]. The only element responsible for the weight loss at the temperature of the thermal decomposition is sulphate decomposition [10]. The TGA results of all the heterogeneous catalysts developed showed accelerated weight loss. Hence, the method is said to be more viable in terms of sulphate retention on the surface of the catalysts.

\subsection{Optimization}

The optimization of biodiesel produced from moringa oleifera seed oil to determine the effect of operating parameters (temperature, time, catalyst concentration, and agitation speed) on biodiesel yield using heterogeneous catalyst produced from snail shells was investigated using $2^{4}$ factorial experimental design. The optimization was carried out via central composite rotatable design matrix (CCRD) and response surface methodology (RMS). The results were analyzed by means of design software (Design Expert) (7.0.0). Table 4 depicts the CCRD design matrix generated.

Table 4. Upper, Lower and Centre Levels of $2^{4}$ Central Composite Design Variables.

\begin{tabular}{llllllll}
\hline S/N & Variable (s) & Symbol (s) & $\mathbf{- 1}$ & $\mathbf{0}$ & $+\mathbf{1}$ & $\mathbf{- \alpha}$ & $+\boldsymbol{\alpha}$ \\
\hline 1. & Temp. $\left({ }^{\circ} \mathrm{C}\right)$ & $\mathrm{X}_{1}$ & 200 & 250 & 300 & 150 & 350 \\
2. & Cat. Conc. $(\mathrm{wt} \%)$ & $\mathrm{X}_{2}$ & 2 & 3 & 4 & 1 & 5 \\
3. & Time (min) & $\mathrm{X}_{3}$ & 120 & 180 & 240 & 60 & 300 \\
4. & Agitation Speed (rpm) & $\mathrm{X}_{4}$ & 200 & 250 & 300 & 150 & 350 \\
\hline
\end{tabular}




\subsubsection{Optimization Process}

A total number of thirty (30) experimental runs were carried out to obtain the actual experimental results for the optimization of moringa oleifera seed oil using snail shells oriented heterogeneous catalyst. Table 5 depicts the percentage yields of experimental results of the optimization of biodiesel production of moringa oleifera seed oil via response surface methodology (RSM) through central composite rotatable design (CCRD) matrix. Experimental percentage yields obtained for all the experimental runs depicted close ranges with the predicted results (Table 5). To this end, whenever the predicted percentages of yields are closer to the percentage experimental yields, it has become more than apparent that the statistical model development seeking to establish valid correlations between the operating parameters (time, temperature, agitation speed and catalyst concentration) is said to be reliable [29]. However, from Table 7, it is deduced that practical percentage yields biodiesel produced from moringa oleifera seed oil at the points of factorization are in line with the statistically predicted percentage yields. According to [30], lower or medium operating parameters can hinder necessary mass transfers needed to complete the reaction. Therefore, this phenomenon is attributed to the use of medium conversion parameters $\left(240 \mathrm{~min}, 300^{\circ} \mathrm{C}, 300 \mathrm{rpm}\right.$ and $\left.4 \mathrm{wt} \%\right)$. It is also observed that biodiesel yields from moringa oleifera seed oil decrease with increase in catalyst concentrations. This trend is attributed to the fact that, the higher the amount of catalyst, the more the triglycerides react with the catalyst thereby forming soap and subsequently leads to decrease in yields [31]. Additionally, the higher the amount of catalyst, the higher the $\mathrm{pH}$ of the methyl ester produced. This may lead the accumulation of deposited catalyst in diesel engines [29]. The ranges for percentage experimental yields recorded of the sixteen (16) points factorized were $13.90 \%$ to $45.50 \%$. At a combination of $240 \mathrm{~min}, 300^{\circ} \mathrm{C}, 300 \mathrm{rpm}$ and $4 \mathrm{wt} \%$, maximum yield was obtained. The report of findings by Alhassan et al. 2014 shows contrary to authors report which shows temperature and time have positive effect on the percentage yield of biodiesel produced [32]. This variation in the effect of operating parameters is attributed to the use of different seed oils. Hence, optimum methyl ester yields at elevated temperatures are mainly the degradation of moringa oleifera seed oil viscosity thereby increasing the rate of the reaction while at the same time increase the yield [33]. Eterigho, 2011, [10] developed and applied heterogeneous catalysts for direct cracking of triglycerides for biodiesel production using the same clay material and reported $59.00 \%$ conversion of methyl ester for solvent free catalyst. However, the difference recorded in the optimum yield of methyl ester $(14.50 \%)$ is attributed to the fact the later only utilized temperature and time whereas this study utilized time, temperature, agitation speed and catalyst concentration in addition to modifying the heterogeneous catalyst produced with snail shells for optimizing the methyl ester yield. Hence, the use of heterogeneous catalyst developed from snail shells ultimately recorded a decrease in methyl ester yield.

Table 5. CCRD Experimental Matrix depicting Observed and Predicted Yields.

\begin{tabular}{|c|c|c|c|c|c|c|}
\hline Run (s) & Factor $1\left(X_{1}\right)$ & Factor $2\left(X_{2}\right)$ & Factor $3\left(X_{3}\right)$ & Factor $4\left(X_{4}\right)$ & Actual Yield (\%) & Predicted Yield (\%) \\
\hline 1 & -1 & -1 & -1 & -1 & 24.90 & 26.04 \\
\hline 2 & +1 & -1 & -1 & -1 & 31.50 & 29.88 \\
\hline 3 & -1 & +1 & -1 & -1 & 19.70 & 22.74 \\
\hline 4 & +1 & +1 & -1 & -1 & 35.70 & 35.75 \\
\hline 5 & -1 & -1 & +1 & -1 & 16.90 & 16.95 \\
\hline 6 & +1 & -1 & +1 & -1 & 27.90 & 27.46 \\
\hline 7 & -1 & +1 & +1 & -1 & 26.60 & 23.82 \\
\hline 8 & +1 & +1 & +1 & -1 & 39.50 & 43.51 \\
\hline 9 & -1 & -1 & -1 & +1 & 32.80 & 32.01 \\
\hline 10 & +1 & -1 & -1 & +1 & 33.40 & 35.84 \\
\hline 11 & -1 & +1 & -1 & +1 & 31.50 & 28.71 \\
\hline 12 & +1 & +1 & -1 & +1 & 40.90 & 41.71 \\
\hline 13 & -1 & -1 & +1 & +1 & 14.50 & 13.83 \\
\hline 14 & +1 & -1 & +1 & +1 & 23.90 & 24.34 \\
\hline 15 & -1 & +1 & +1 & +1 & 18.50 & 20.71 \\
\hline 16 & +1 & +1 & +1 & +1 & 44.50 & 40.39 \\
\hline 17 & $-\alpha$ & 0 & 0 & 0 & 13.90 & 13.45 \\
\hline 18 & $+\alpha$ & 0 & 0 & 0 & 38.50 & 36.97 \\
\hline 19 & 0 & $-\alpha$ & 0 & 0 & 27.80 & 27.65 \\
\hline 20 & 0 & $+\alpha$ & 0 & 0 & 40.50 & 40.40 \\
\hline 21 & 0 & 0 & $-\alpha$ & 0 & 37.70 & 36.68 \\
\hline 22 & 0 & 0 & $+\alpha$ & 0 & 25.50 & 26.27 \\
\hline 23 & 0 & 0 & 0 & $-\alpha$ & 22.60 & 23.79 \\
\hline 24 & 0 & 0 & 0 & $+\alpha$ & 22.50 & 26.64 \\
\hline 25 & 0 & 0 & 0 & 0 & 30.70 & 25.21 \\
\hline 26 & 0 & 0 & 0 & 0 & 23.40 & 25.21 \\
\hline 27 & 0 & 0 & 0 & 0 & 24.50 & 25.21 \\
\hline 28 & 0 & 0 & 0 & 0 & 22.10 & 25.21 \\
\hline 29 & 0 & 0 & 0 & 0 & 26.50 & 25.21 \\
\hline 30 & 0 & 0 & 0 & 0 & 27.90 & 25.21 \\
\hline
\end{tabular}




\subsubsection{Statistical Analysis of Variance (ANOVA)}

Statistical analysis of variance on the optimization of biodiesel production from moringa oleifera seed oil using snail shells $\mathrm{CaO}$ based heterogeneous catalyst was employed mainly for the purpose of estimating the effects of major reaction parameters relative to methyl ester yield. Table 6 depicts the response surface reduced cubic equation based on partial statistical sum of squares type III. According to Noordin, et al. 2004, partial statistical sum of squares is said to be the sum of squares relative and corresponding to each and every effect adjusted for each and every other effect in the statistical equation selected after reproducibility test of the equation often suggested by the software used (Design Expert 7.0.0) and relatively compared with the results obtained; whereas the terms that appear insignificant in the equation are often corrected automatically via backward (s) cum stepwise (s) correction equation [34]. From the results obtained, it is statistically clear that the four (4) reaction variables under study (temperature, time, catalyst concentration, and agitation speed) cum the statistical equation appear to be statistically significant $p<.01$. In statistics, a P-value lesser than 0.05 is a clear indication that the statistical equation generated is significant as a result of reasonably large number of each and every significant term needed to indicate effects on the responses and were sufficiently and reasonably enough to represent the actual relationship between the response and the independent variables [18, 33]. The intercept recorded from the coefficient estimate showed $78.85 \%$. The major effects of the variables (temperature, time, catalyst concentration, and agitation speed) depict significances of $\mathrm{p}<.01$. Hence, the relationship of the variables under study in the prediction of the linearity of independent factors and their interactions in surface response is represented by second order polynomial equation (Equation 1.) [35].

$$
Y=\alpha_{O}+\sum_{i=1}^{3} \alpha_{1} x_{1}+\sum_{i=1}^{3} x_{i i} x_{2}^{2}+\sum \Sigma_{i<j=1}^{3} \alpha_{i j} x_{i} x_{j}
$$

Where:

$\mathrm{Y}=$ Biodiesel Yield

$\alpha_{\mathrm{o}}=$ Intercept

$\mathrm{xi}$ and $\mathrm{x}_{\mathrm{j}}=$ uncoded independent variables

$\alpha_{\mathrm{i}}, \alpha_{\mathrm{ii}}$ and $\alpha_{\mathrm{ij}}=$ linear, quadratic and interaction constant coefficients respectively

Table 6. Statistical Analysis of Variance.

\begin{tabular}{|c|c|c|c|c|c|c|}
\hline Source & Sum of Squares & df & Mean Square & F-Value & P-Value & Remark \\
\hline Model & 1758.27 & 14 & 125.59 & 73.35 & $<0.0001$ & Significant \\
\hline A-Temp. & 447.21 & 1 & 447.21 & 261.18 & $<0.0001$ & Significant \\
\hline B-Time & 64.68 & 1 & 64.68 & 37.78 & $<0.0001$ & Significant \\
\hline C-Cat. Con. & 47.60 & 1 & 47.60 & 27.80 & $<0.0001$ & Significant \\
\hline D-Agitation Speed & 30.83 & 1 & 30.83 & 18.00 & 0.0007 & Significant \\
\hline $\mathrm{AB}$ & 283.92 & 1 & 283.92 & 165.82 & $<0.0001$ & Significant \\
\hline $\mathrm{AC}$ & 259.21 & 1 & 259.21 & 151.39 & $<0.0001$ & Significant \\
\hline $\mathrm{AD}$ & 141.61 & 1 & 141.61 & 82.71 & $<0.0001$ & Significant \\
\hline $\mathrm{BC}$ & 152.52 & 1 & 152.52 & 89.08 & $<0.0001$ & Significant \\
\hline $\mathrm{BD}$ & 214.62 & 1 & 214.62 & 125.35 & $<0.0001$ & Significant \\
\hline $\mathrm{CD}$ & 4.84 & 1 & 4.84 & 2.83 & 0.1134 & Not Significant \\
\hline $\mathrm{A}^{2}$ & 41.58 & 1 & 41.58 & 24.28 & 0.0002 & Significant \\
\hline$B^{2}$ & 1.31 & 1 & 1.31 & 0.77 & 0.03951 & Not Significant \\
\hline $\mathrm{C}^{2}$ & 2.17 & 1 & 2.17 & 1.27 & 0.2780 & Not Significant \\
\hline $\mathrm{D}^{2}$ & 64.31 & 1 & 64.31 & 37.56 & $<0.0001$ & Significant \\
\hline Residual & 25.68 & 15 & 1.71 & & & \\
\hline Lack of Fit & 21.71 & 10 & 2.17 & 2.73 & 0.1395 & Not Significant \\
\hline Pure Error & 3.97 & 5 & 0.79 & & & \\
\hline Cor Total & 1783.95 & 20 & & & & \\
\hline R-Squared & 0.9856 & 29 & & & & \\
\hline
\end{tabular}

\subsubsection{Effects of Operating Parameters on Biodiesel Yield}

From the ANOVA analysis (Table 6), it is deduced that temperature, time, catalyst concentration and agitation speed are significant independent variables. Also the interaction of temperature and reaction time $(\mathrm{AB})$, temperature and catalyst concentration (AC), temperature and agitation speed (AD), time and catalyst concentration (BC), time and agitation speed (BD) are significant for first (1st) order polynomial while temperature and agitation speed are significant for second $\left(2^{\text {nd }}\right)$ order polynomial. On the other hand, time and catalyst concentration are not significant for second $\left(2^{\text {nd }}\right)$ order polynomials. It has become more than apparent that all variables have effect on biodiesel yield (response). For a variable to be significant in $1^{\text {st }}$ order and $2^{\text {nd }}$ polynomials, it does not statistically signifies ascending or descending effects on the yield of methyl ester, instead it only signifies that whenever such a variable is intensified and vice-versa a corresponding increase or decrease is expected in the outcome, that is, biodiesel yield. It is conveniently deduced from the analysis of statistical results that the process variables and their interaction effects have varying impacts on the yield biodiesel produced from moringa oleifera seed oil using snail oriented heterogeneous catalyst. The response surface plots of the optimization process were plotted for the 
effect two (2) variables at a time and keeping other constant thereby highlighting the effects of these variables on the yield as shown in Figure 14. The 2D contour plots between the quantities of two variables at various levels depict a
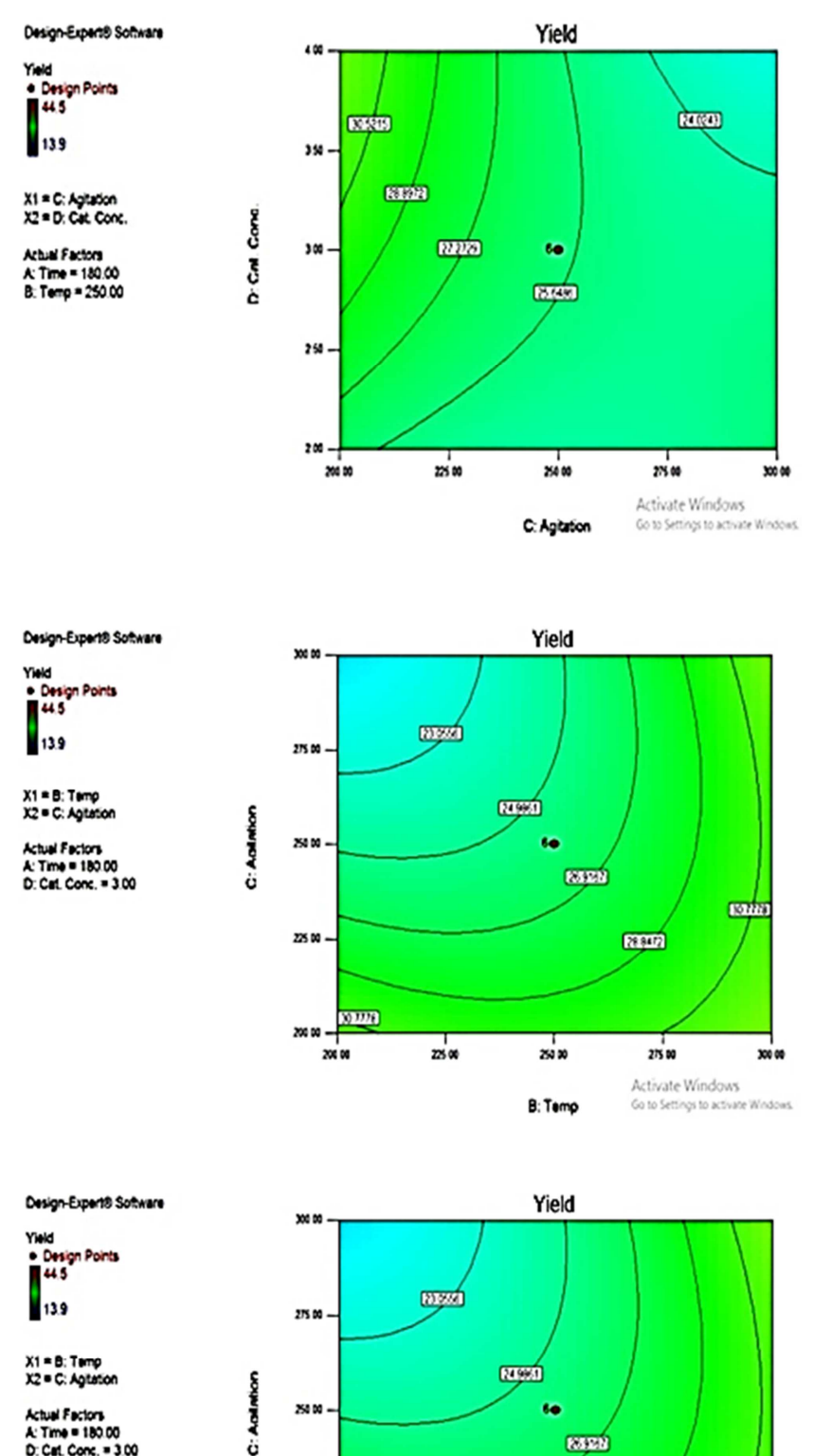

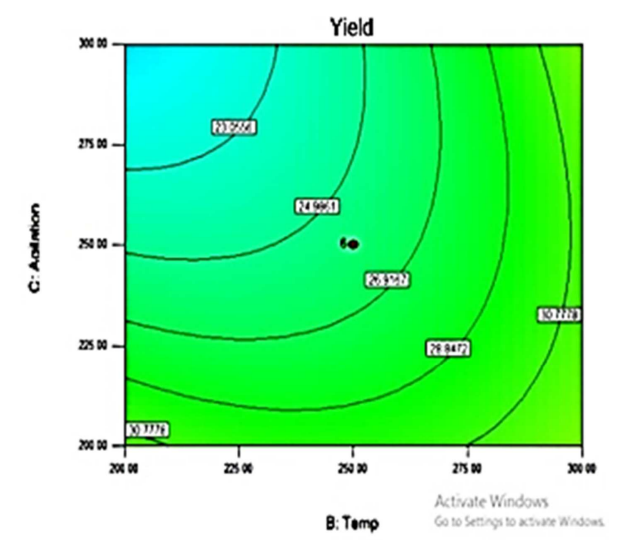

corresponding percentage methyl ester yields and vice-versa. Hence, the contour plots are also significant mechanisms used in the interpretation of the interactions of two (2) variables at a time while keeping the others constant.
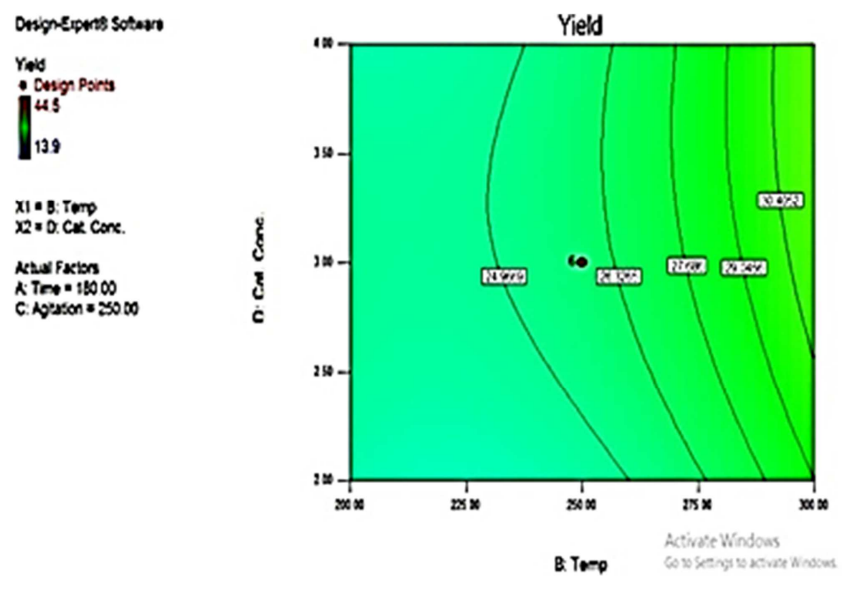

arignerpensosons
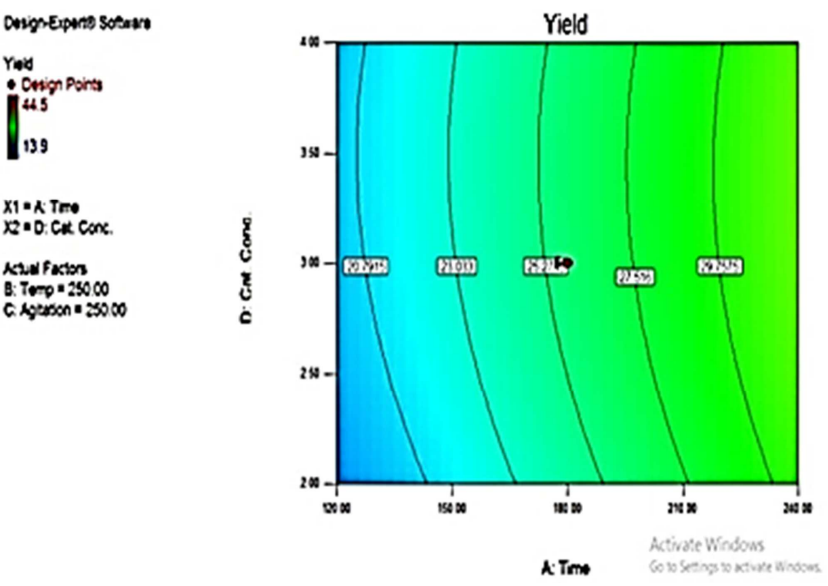

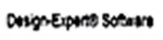

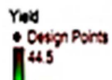

139

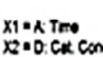
$x=0.0 \times C \cos$ Bief foxion

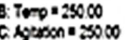

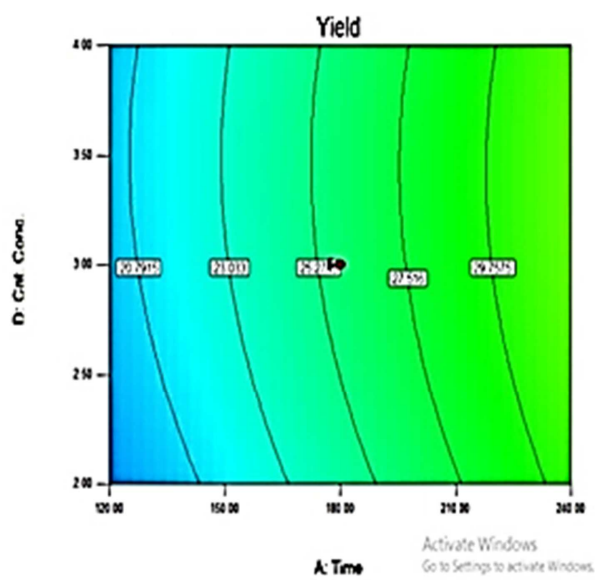

Figure 14. 2D Contour Plots of Operating Parameters and their Corresponding Effects on Biodiesel Yields.

\subsubsection{Statistical Response Equations in Terms of Coded and Actual Factors}

For the purpose of ascertaining the independent and interactive contributions of the variables under study (temperature, time, catalyst concentration and agitation speed), the linear statistical response model is used for both values (coded and actual) of the methyl ester yield. Equations
(2) and (3) depict the response equation in terms of coded and actual factors respectively. The linear statistical models also depict the coefficients of all the variables in the linear regression equations, their statistical significances and their corresponding impacts on the yield of biodiesel from moringa oleifera seed oil. According to Abdullah et al. 2009, the positive and/or negative signs attached to individual terms and their interactions are indications of synergistic and 
antagonistic effects on the methyl ester yield [36].

$$
\begin{array}{r}
\text { Yield }=+25.85+5.88 * \mathrm{~A}+3.19 * \mathrm{~B}-2.60 * \mathrm{C}+0.71 * \mathrm{D}+2.29 * \mathrm{~A} * \mathrm{~B}+1.67 * \mathrm{~A} * \mathrm{C}-0.069 * \mathrm{~A} * \mathrm{D}+ \\
2.54 * \mathrm{~B} * \mathrm{C}+0.66 * \mathrm{~B} * \mathrm{D}-2.27 * \mathrm{C} * \mathrm{D}+0.14 * \mathrm{~A}^{2}+2.12 * \mathrm{~B}^{2}+1.49 * \mathrm{C}^{2}-0.78 * \mathrm{D}{ }^{2}(2) \\
\text { Yield }+185.88750-0.2424 * \mathrm{t}-0.79242 * \mathrm{~T}-0.56775 * \mathrm{~A}+13.63750 * \mathrm{CC}+7.64583 \mathrm{E}-004 * \mathrm{t} * \mathrm{~T}+ \\
5.56250 \mathrm{E}-004 * \mathrm{t} * \mathrm{~A}-1.14583 \mathrm{E}-003 * \mathrm{t} * \mathrm{CC}+1.01750 \mathrm{E}-003 * \mathrm{~T} * \mathrm{~A}+0.013125 * \mathrm{~T} * \mathrm{CC}-0.045375 * \mathrm{~A} * \\
\mathrm{CC}+3.79051 \mathrm{E}-005 * \mathrm{t}^{2}+8.49583 \mathrm{E}-004 * \mathrm{~T}+5.94583 \mathrm{E}-004 * \mathrm{~A}^{2}-0.77604 * \mathrm{CC}{ }^{2}(3)
\end{array}
$$

Where:

$\mathrm{t}=$ Time

$\mathrm{T}=\mathrm{Temp}$

$\mathrm{A}=$ Agitation

$\mathrm{CC}=$ Catalyst Concentration

\subsubsection{Reliability of the Statistical Model}

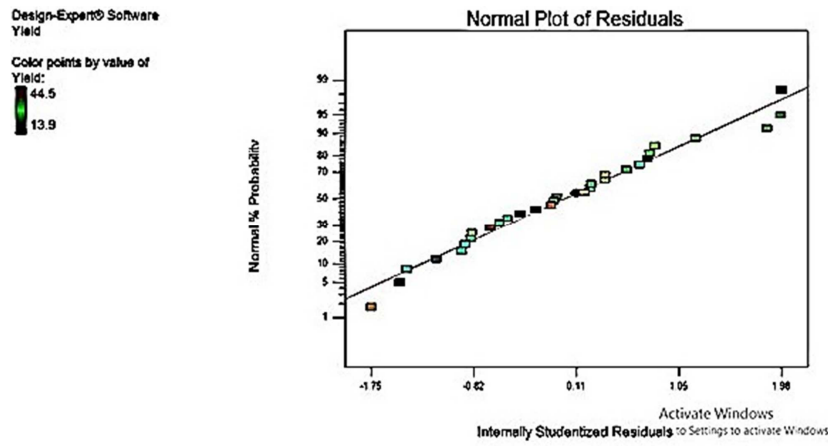

Figure 15. Normal and Probability Plots of Residuals.
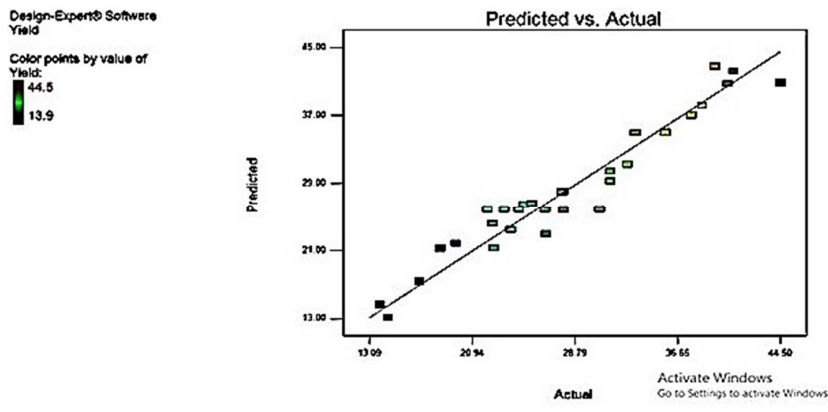

Figure 16. Plots of Predicted Biodiesel Yields versus Actual Biodiesel Yields.

To determine the reliability of the statistical model for the optimization of biodiesel production from moringa oleifera seed oil, the coefficient of determination otherwise known as $\mathrm{R}$-squared $\left(\mathrm{R}^{2}\right)$ value is paramount because it indicates the fitness of the linear regression model developed. As a rule of thumb, the closer the R-squared value to unity, the higher the precision of the model. It can be deduced from the R-square value that $98.56 \%$ of the methyl ester produced has been accounted for by the linear regression equation generated while $1.44 \%$ of the entire variations experienced on the response of the biodiesel produced could not be explained by the linear regression equation generated. Additionally, the reliability of the linear regression model is ascertained by the values of standard deviation (1.31); the mean (77.04) and the adjusted $R^{2}$ value $(0.9722)$. All the statistical information gathered were employed for the purpose of predicting the optimum response of the biodiesel produced. Summarily, the outcomes have shown that the optimal response of biodiesel obtained for experimental result was $99.00 \pm 1.70 \%$ at a confidence level of $95.00 \%$. Figure 15 depicts the probabilities of evaluating the optimum points of the actual and the predicted yields while Figure 16 depicts the parity plot of experimental (actual) yields versus the predicted yields for the total number of experiments carried out during the study.

\subsubsection{FTIR}

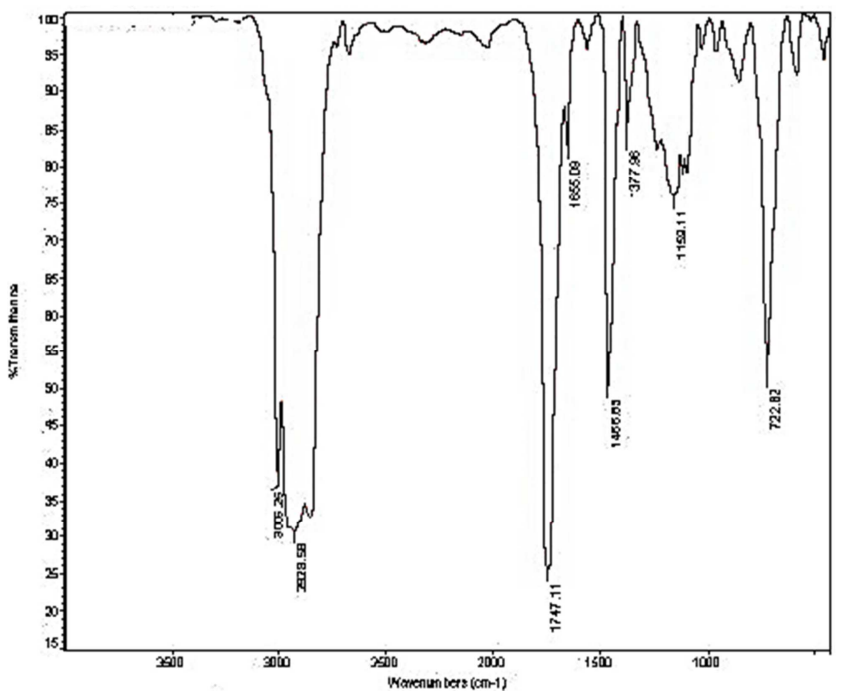

Figure 17. FTIR Spectra of Moringa Oleifera Biodiesel using Snail Shells oriented Heterogeneous Catalyst.

The FTIR analysis was carried out on the biodiesel produced mainly to classify the unknown compounds through identifying their functional groups. The infrared (IR) spectrum appeared to lie between approximately $4000-500 \mathrm{~cm}^{-1}$. The IR obtained is segmented into two (2). The first being the left segment, that is, between $2000 \mathrm{~cm}^{-1}$ and above, this segment is often made up of peaks that are usually and relatively few in numbers with significant analytical information. On the other hand, the second segment is made up of numerous peaks in the range of $2000 \mathrm{~cm}^{-1}$ to $500 \mathrm{~cm}^{-1}$. However, the peaks identified in both segments were ascertained via comparisons with established spectrums. Figure 17 depicts the peak in the regions at $3005 \mathrm{~cm}^{-1}, 2908 \mathrm{~cm}^{-1}$ (first segment); $1747 \mathrm{~cm}^{-1}$, $1655 \mathrm{~cm}^{-1}, 1405 \mathrm{~cm}^{-1}, 1377 \mathrm{~cm}^{-1}, 1199 \mathrm{~cm}^{-1}$ and $722 \mathrm{~cm}^{-1}$ depict the existence of $\mathrm{C}-\mathrm{CH}_{3}, \mathrm{CH}_{2}, \mathrm{CH}_{3}, \mathrm{C}-\mathrm{O}, \mathrm{CH}=\mathrm{CH}$ trans, and $\mathrm{CH}=\mathrm{CH}$ cis respectively.

\subsection{6. $G C-M S$}

GC-MS analysis was primarily employed to determine the 
methyl ester groups present in the biodiesel produced using $\mathrm{NaOH}$. Figure 18 depicts the GC-MS analysis of biodiesel produced from moringa oleifera seed oil. Four (4) major fatty acid methyl esters (FAMEs) characteristic peaks that appear by the retentions of time and the fragmentation pattern data of GC-MS analysis were observed. The FAMEs peaks identified are C16:1, C18:0, C18:1 and CI8:2 respectively, that is, Palmitoleic acid methyl ester, Stearic acid methyl ester, Oleic acid methyl ester and Linoleic acid methyl ester.

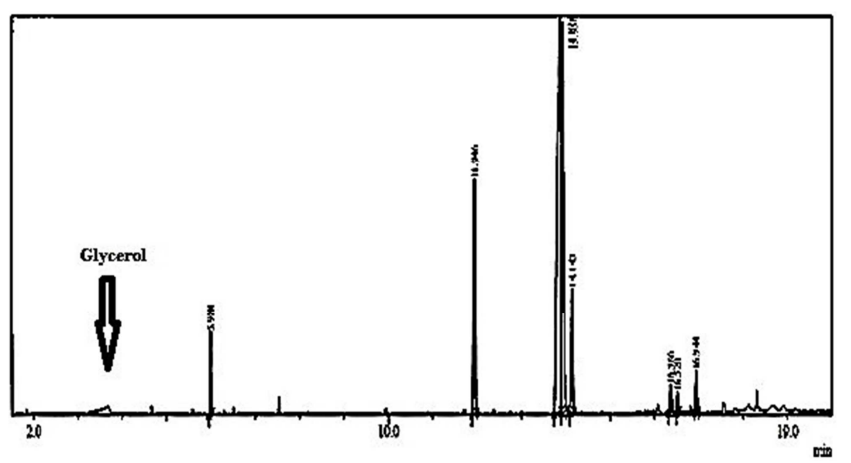

Figure 18. GC-MS Analysis of Moringa Oleifera Biodiesel using Snail Shells oriented Heterogeneous Catalyst.

\subsubsection{Analysis of the Properties of Biodiesel Produced from Snail Shells oriented Heterogeneous Catalyst}

\section{(i) Density}

The density of the biodiesel produced was determined at $15^{\circ} \mathrm{C}$. It is often employed in judging the level of homogeneity in biodiesel samples [37]. Biodiesel density is a significant parameter primarily because it influences the efficiencies of atomization in airless diesel combustion engines [38]. The density recorded in this study $\left(0.85 \mathrm{gcm}^{-3}\right)$ depict that the biodiesel produced from snail shells oriented heterogeneous catalyst falls within the range specified by ASTM standard (Table 7). Also, the density obtained from the study is in agreement with the findings in literature most of which are $0.865 \mathrm{gcm}^{-3}, 0.81 \mathrm{gcm}^{-3}$ and $0.89 \mathrm{gcm}^{-3}$ for sunflower oil, neem seed oil and peanut oil respectively [16, $39,40]$. The slight variations may be attributed to the nature of oil extraction and soil morphology of the oil seeds used.

\section{(ii) Total Glycerin}

Total glycerol is the sum of the concentrations of free glycerol and glycerol bound in the form of mono-, di-and triglycerides. The concentration depends on the production process [41]. The percentage total glycerin recorded in this study $(0.29 \%)$ depict that the biodiesel produced from snail shells oriented heterogeneous catalyst is $0.05 \%$ higher than the range specified by ASTM standard (Table 7). Though negligible, the biodiesel produced may slightly be prone to coking of diesel engines and may also cause slight formation of deposits on diesel engine injector nozzles and valves [41].

\section{(iii) Viscosity}

Viscosity of biodiesel is simply the amount of its resistance to flow at a given temperature. The viscosity of the biodiesel produced was determined at $40^{\circ} \mathrm{C}$. The viscosity recorded from this study $\left(5.00 \mathrm{~mm}^{2} \mathrm{~s}^{-1}\right)$ is less than the maximum viscosity specified by ASTM standards (Table 7) and it is in consonant with the viscosities of palm oil $\left(4.90 \mathrm{~mm}^{2} \mathrm{~s}^{-1}\right)$; neem seed oil $\left(5.30 \mathrm{~mm}^{2} \mathrm{~s}^{-1}\right)$ and peanut oil $\left(5.32 \mathrm{~mm}^{2} \mathrm{~s}^{-1}\right)$ reported in literature $[16,39,40]$. Hence, the biodiesel produced will not hinder full operation of any diesel engine.

\section{(iv) Acid Value}

The acid value of the biodiesel produced is an important parameter that determines the quality of the biodiesel produced from moringa oleifera seed oil using snail shell oriented heterogeneous catalyst. According to Cancela et al. 2015, acid value of biodiesel indicates the degree or extent at which the product will be stored and transported because larger quantities of free fatty acids (FFAs) often cause corrosion in storage and transportation tanks [42]. The acid value recorded in this study $\left(0.28 \mathrm{mgKOHg}^{-1}\right)$ is lower the values put forward by Ivanoiu et al. 2011; Oyerinde and Bello, 2016, who reported $0.20 \mathrm{mgKOHg}^{-1}$ and $0.45 \mathrm{mgKOHg}^{-1}$ for soybean oil and peanut oil respectively. The decrease in acid value recorded from the virgin oil stood at $98.50 \%$. This indicates a good transesterification process by the catalyst developed $[16,40]$.

\section{(v) Iodine Value}

Iodine value is often determined and used as a measure for the saturation or unsaturation of fatty acids [43]. The higher the iodine value, the higher the tendency of the biodiesel produced to oxidation and the formation of deposits in injectors of diesel engines [42]. However, iodine value recorded in this study (Table 7) is lower than $77.17 \mathrm{mg} \mathrm{I}_{2} / 100$ $\mathrm{g}$ oil and $102 \mathrm{mg} \mathrm{I}_{2} / 100 \mathrm{~g}$ oil reported in literature, [45-46].

\section{(vi) Sulphated Ash}

Biodiesel of any kind is said to be free of Sulphur [46], therefore, the determination of sulphated ash in this study is aimed at ascertaining the level of contamination by carry-over catalyst materials [47]. The presence of sulphur in biodiesel retards the efficiency of catalyst developed and ultimately causes sulphur oriented emissions in diesel engines thereby resulting in the formation of black smoke that causes irritation of the eyes, skin and even causes cancer [37]. The sulphated ash recorded in this study is $0.016 \mathrm{wt} \%$ and is in agreement with the sulphur percentage weight content of biodiesel, that is, from $0.031 \mathrm{wt} \%$ to $0.05 \mathrm{wt} \%$. The use of the biodiesel produced aids the performance diesel engines due to lesser emissions $[9,48]$.

\section{(vii) Cetane Number}

Cetane number describes the quality in terms of ignition from the biodiesel produced [49]. As a dimensionless quantity, cetane number is a prime indicator of biodiesel quality because it measures how easier the biodiesel ignites in a diesel engine [50]. Compared to petrol diesel, biodiesel has higher cetane number due to higher oxygen contents [51]. The cetane number obtained from this study is 54.87 , which is greater than that of peanut oil (54.00) reported by Oyerinde 
and Bello, 2016 but lower than that of rapeseed oil (58.00); palm oil (65.00); lard (65) and beef tallow (75) reported by Hilber et al. [40], [52].

\section{(viii) Cloud and Pour Points}

Cloud point is the temperature at which crystals first appear in the biodiesel when cooled [53]. In polar regions and at temperatures below cloud point temperature, there exist larger biodiesel crystals that often fuse together and form bigger agglomerate which hinder the flow biodiesel in both fuel lines and filters thereby causing engine start-up and performance problems [54]. In the same vein, the temperature at which crystal agglomeration is pronounced and capable of preventing the free pouring of biodiesel is termed as the pour point of the biodiesel [55]. $-5^{\circ} \mathrm{C}$ and $-7^{\circ} \mathrm{C}$ were the observed cloud and pour points of the biodiesel produced respectively. Hence, the biodiesel produced would be more suitable to use in polar regions than the petro-diesel.

\section{(ix) Flash Point}

Flash point is the temperature that measures the ability of the biodiesel produced to form flames with air evenly available [54-55]. It is an important parameter that ascertains the flammability hazard of the biodiesel produced. The study recorded a flash point of $180^{\circ} \mathrm{C}$. As such, the biodiesel produced has lesser tendencies of creating fire hazard and auto-ignition at higher temperatures during storage and transportation periods [37].

\section{(x) Calorific value}

The calorific value of the biodiesel produced is said to be a property provides the suitability or otherwise of using fatty compounds as fuels in diesel engines [37]. The value obtained from this study $\left(42.00 \mathrm{MJKg}^{-1}\right)$ is said to be acceptable for its suitability as a fuel for diesel engines. It compares favourably with the value put forward by [37] and appears higher than the current calorific value put forward by the European (EU) standard for biodiesel $\left(32.9 \mathrm{MJKg}^{-1}\right)$.

\section{(xi) Saponification Value}

The Saponification value obtained from this study (87) is an indication that the biodiesel produced has lower saponification value than the virgin moringa oleifera oil.

\subsection{Kinetic Analysis}

Table 7. Properties of Biodiesel Produced.

\begin{tabular}{llllll}
\hline S /N & Properties & Unit (s) & Exp. & ASTM & Diesel \\
\hline 1. & Density@ $15^{\circ} \mathrm{C}$ & $\mathrm{gcm}^{-3}$ & 0.850 & $0.900_{\max }$ & 0.800 \\
2. & Total Glycerine & $\%$ & 0.290 & $0.240_{\max }$ & - \\
3. & Viscosity@ $40^{\circ} \mathrm{C}$ & $\mathrm{mm}^{2} \mathrm{~s}^{-1}$ & 5.000 & $6.00_{\max }$ & $16.50_{\max }$ \\
4. & Acid Value & $\mathrm{mgKOHg}^{-1}$ & 0.280 & 0.500 & - \\
5. & Iodine Value & $\mathrm{g} \mathrm{of} \mathrm{I}_{2} / 100 \mathrm{~g}$ Oil & 70.90 & - & - \\
6. & Sulphated Ash & $\mathrm{Wt} \%$ & 0.016 & $0.050_{\max }$ & $0.300_{\max }$ \\
7. & Cetane Number & - & 54.00 & $47.00_{\min }$ & 51.00 \\
8. & Cloud point & ${ }^{\circ} \mathrm{C}$ & -5.00 & -3 to 12 & -14.50 \\
9. & Flash Point & ${ }^{\circ} \mathrm{C}$ & 180.0 & $130_{\min }$ & $166_{\max }$ \\
10. & Pour Point & ${ }^{\circ} \mathrm{C}$ & -7.00 & -15 to 10 & - \\
11. & Saponification Value & $\mathrm{mgKOHg}{ }^{-1}$ & 87.00 & - & - \\
12. & Calorific Value & $\mathrm{MJKg}^{-1}$ & 42.00 & - & - \\
\hline
\end{tabular}

Kinetic analyses of moringa oleifera seed oil biodiesel production using $\mathrm{CaO}$ based heterogeneous catalyst developed from snail shells was carried out via empirical approach method. This method is visible because it describes the relationship of the operating parameters to the final quantity of the biodiesel produced.

Table 7 shows summary of the produced biodiesel as comparison with the standard.

\subsection{Order of the Reaction}

Table 8. Summary of First and Second Order Kinetic Parameters.

\begin{tabular}{llll}
\hline \multirow{2}{*}{ S/N } & Temp. $\left({ }^{\circ} \mathbf{C}\right)$ & R-Squared & \\
\cline { 3 - 4 } & & First $\left(\mathbf{1}^{\text {st }}\right)$ Order & Second $\left(2^{\text {nd }}\right)$ Order \\
\hline 1. & 100 & 0.9331 & 0.9329 \\
2. & 200 & 0.9154 & 0.9046 \\
3. & 300 & 0.9100 & 0.8595 \\
4. & 400 & 0.8087 & 0.5478 \\
\hline
\end{tabular}

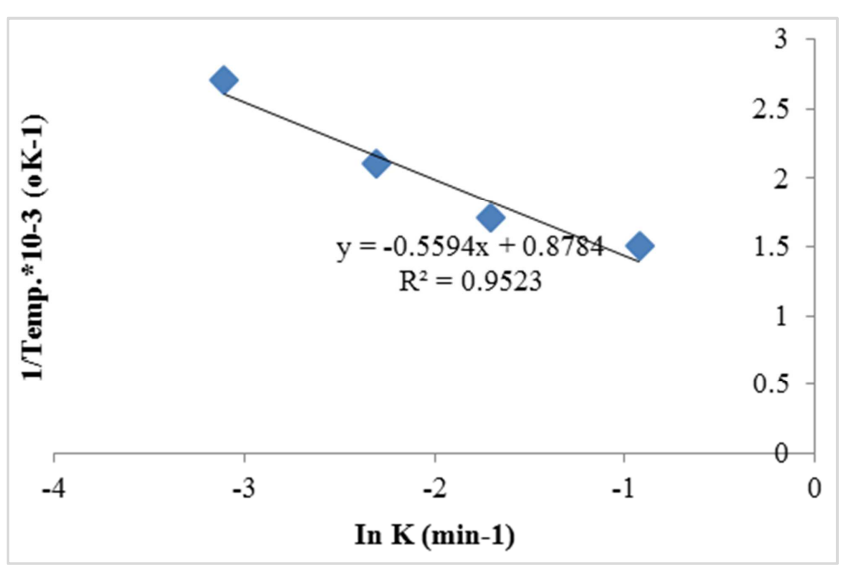

Figure 19. Inverse of Temperature versus In $K$ (Slope) for the Determination of Activation Energy.

First and second order kinetics using empirical (integral) approaches were tested between $100^{\circ} \mathrm{C}$ to $400^{\circ} \mathrm{C}$. Equations $3.9,3.10$ and 3.12 were used for the determination of first order kinetics, second order kinetics and the determination of activation energy $\left(E_{a}\right)$ of the production process respectively. The production of biodiesel from moringa oleifera seed oil obeys first order kinetics, the reaction proceeds faster at elevated temperatures. The calculated activation $\left(\mathrm{E}_{\mathrm{a}}\right)$ recorded is $3.13 \mathrm{kJmol}^{-1} \mathrm{~K}^{-1}$. Table 8 depicts the summary of first and second order parameter obtained from the reaction while Figure 19 depicts the plot of the inverse of temperature $\left({ }^{\circ} \mathrm{K}\right)$ against In K (slope) for the determination of activation energy.

\section{Conclusion}

Ukpor clay and snail shells were found useful in the development of heterogeneous catalyst and the catalyst was found to be excellently active for the production of biodiesel, that is, the transesterification of Moringa Oleifera seed oil. Quite a number of catalysts' physicochemical properties molecular structures, compounds of interest, porosity, grain sizes, elemental proportions, surface areas, IR spectra and 
weight losses and morphologies obtained from XRF, FTIR, SEM, XRD, EDS, BET, XPS and TGA analyses were observed to be responsible for the catalytic efficiency recorded The density, total glycerin, viscosity, acid value, iodine value, sulphated ash, cetane number cloud point, flash point, pour point, saponification value and calorific value of the biodiesel produced conform to ASTM standard. These abundant raw materials (Ukpor clay and snail shells) are useful in the development of catalysts for biodiesel production.

\section{References}

[1] Ma, F. and Hanna, M. (199). Biodiesel production: A Review, Bioresource Technology, 70, 1-15.

[2] Fukuda, H., Kondo, A. and Noda, H. (2001) Biodiesel Fuel Production by Transesterification of Oils, Journal of Bioscience and Bioengineering, 92 (5), 405-416.

[3] Kiss, A., Dimian, A. and Rothenberg, G (2008). Biodiesel by Catalytic Reactive Distillation Powered by Metal Oxides, Energy Fuel, 22 (1), 598-604.

[4] Yusuf, N., Kamarudin, S. and Yaakob, Z. (2012). Overview on the Production of Biodiesel from Jatropha Curcas L. by using Heterogenous Catalysts, Biofuels, Bioproducts and Biorefining, $6(3), 319-334$

[5] Lee, H., Juan, J. and Abdullah, N. (2014). Heterogeneous Base Catalysts for Edible Palm and Non-edible Jatropha-Based Biodiesel Production, Chemistry Central Journal, 8 (30).

[6] Yan, S., Lu, H. and Liang, B. (2008). Supported $\mathrm{CaO}$ Catalysts used in the Transesterification of Rapeseed Oil for the Purpose of Biodiesel Production, Energy Fuel, 22, 646651.

[7] Cho, Y., Seo, G. and Chang, D. (2009). Transesterification of Tributyrin with Methanol over Calcium Oxide Catalysts Prepared from Various Precursors, Fuel Process Technol, 90, $1252-1258$

[8] Kouzu, M., Kasuno, T., Tajika, M., Sugimoto, Y., Yama-naka, S. and Hidaka, J. (2008). Calcium Oxide as a Solid Base Catalyst for Transesterification of Soybean Oil and its Application to Biodiesel Production, Fuel, 87, 2798-2806.

[9] Ameh, C. U. (2018). Process Optimization Kinetic Modelling and Characterization of Biodiesel Produced from Moringa Oleifera Oil. PhD Progress Report Submitted in the Department of Chemical Engineering, Federal University of Technology, P. M. B. 65, Gidan Kwano Campus, Minna, Niger State, Nigeria.

[10] Eterigho, E. (2011). Development and Application of Heterogeneous Catalysts for Direct Cracking of Triglycerides for Biodiesel Production, A PhD Thesis, School of Chemical Engineering and Advanced Materials, 1-156.

[11] Etuk, B. R., Idongesit, Etuk, F and Linus O. A. (2012). Feasibility of Using Sea Shells Ash as Admixtures for Concrete. Journal of Environmental Science and Engineering A 1 (1) 121-127, ISSN 1934-8932.

[12] Benzidane, D., Baba, M. and Abi-Ayad, S. (2017). Biodiesel Production from Marine Microalgae Nannochloropsis gaditana by in situ Transesterification Process, African Journal of Biotechnology, 16 (22), 1270-1277.

[13] Natthanicha, S. and Siriwan, M. (2017). The Development of Biodiesel Production from Vegetable Oils by Using Different Proportions of Lime Catalyst and Sodium Hydroxide, 2017 International Conference on Alternative Energy in Developing Countries and Emerging Economies 2017, Bangkok, Thailand Energy, 991-997.

[14] Widayat, H., Oki, Y. and Djoko, M. (2013). Biodiesel Production from Bulk Frying Oil with Ultrasound Assisted, Research Journal of Applied Sciences, Engineering and Technology, 6 (10), 1732-1739.

[15] Asri, N., Podjojono, B., Fujiani, R. and Nuraini, A. (2017). Utilization of Eggshell Waste as Low-Cost Solid Base Catalyst for Biodiesel Production from Used Cooking Oil, 7th International Conference on Environment and Industrial Innovation, 67.

[16] Ivanoiu, A., Schmidt, F., Peter, L. and Ungurean, M. (2011). Comparative Study on Biodiesel Synthesis from Different Vegetables Oils, Chemical Bulletin of "Politehnica" University of Timisoara, Romania, Series of Chemistry and Environmental Engineering, Chem. Bull. "POLITEHNICA" Univ. (Timisoara), 56 (70), 94-98.

[17] Mohammed, S., Aroua M., Mariod A., Sit, F., Malik, A., Abdelrahman, A. and Atabani, G. (2015). Physico-chemical characterization and thermal Behavior of Biodiesel and Biodiesel-Diesel Blends Derived from Crude Moringa Peregrina Seed Oil, Elsevier Journal of Energy Conversion and Management, 92, 535-542.

[18] Thembi, S., Kalala, J. and Reinout, M. (2014). Biodiesel Production from Waste Vegetable Oils over $\mathrm{MgO} / \mathrm{ZrO}_{2}$ Catalyst, Proceedings of the World Congress on Engineering, Vol. II, London, U.K.

[19] Zhen, M. and Francisco, Z. (2001). Characterization of Heterogeneous Catalysts, Chapter One, Wiley Publishers, Pp. $1-39$.

[20] Roschat, W. and Siritanon, T. (2016). Biodiesel Production from Palm Oil using Hydrated Lime-Derived $\mathrm{CaO}$ as a Low-Cost Basic Heterogeneous Catalyst, Energy Conversion and Management, 108, 459-467.

[21] Teo, S., Rashid, U. and Taufiq-Yap, Y. (2014). Biodiesel Production from Crude Jatropha Curcas Oil using Calcium Based Mixed Oxide Catalysts, Fuel, 136, 244-252.

[22] Bamgboye, A. and Hansen, A. (2008). Prediction of Cetane Number of Biodiesel Fuel from the Fatty Acid Methyl Ester (FAME) Composition, International Journal of Agrophys., 22 (1), 21-29.

[23] Qian, F. W., Liu, S. and Yun, Z. (2008). In situ alkaline transesterification of cottonseed oil for production of biodiesel and nontoxic cottonseed meal. Bioresource Technology, vol. 99, pp. 9009-9012.

[24] Arandiyan, H. and Parvari, M. (2009). Studies on Mixed Metal Oxides Solid Solutions as Heterogeneous Catalysts, Brazilian Journal of Chemical Engineering, 26 (1), 63-74.

[25] Ndanganeni, M., Ephraim, V., Reinout, M. and Kalala, J. (2010). Biodiesel Production over $\mathrm{ZnO} / \mathrm{TiO}_{2}$ Catalyst: Effect of Co-solvent, Temperature and Reaction Time, Proceedings of the World Congress on Engineering, Vol. II, London, U.K. 
[26] Aldes, L., Palita, T., Risfidian, M. and Fahmariyanti, A. (2013). Preparation of Calcium Oxide from Achatina Fulica as Catalyst for Production of Biodiesel from Waste Cooking Oil, Indo. J. Chem., 13 (2), 176-180.

[27] Sujan, S., Gajanan, S., Sudipta, D., Prakash, C., Satyanarayan, N. (2017). Methanolysis of Jatropha Curcas Oil using $\mathrm{K}_{2} \mathrm{CO}_{3} / \mathrm{CaO}$ as a Solid Base Catalyst, Turkish Journal of Chemistry, 41, 845-861.

[28] Farook, A., Saraswathy, B. and Phee-Lee, W. (2006). Rice Husk Ash Silica as a Support Material for Ruthenium Based Heterogeneous Catalyst, Journal of Physical Science, 17 (2), 1-13.

[29] Leung, D., Wu, X. and Leung, M. (2011). A Review on Biodiesel Production using Catalyzed Transesterification, Journal of Applied Energy, 87 (4), 1083-1095.

[30] Dharmesh-Kumar, N. and Math, M. (2016). Application of Response Surface Methodology for Optimization of Biodiesel Production by Transesterification of Animal Fat with Methanol, International Journal of Renewable Energy, 6 (1), 74-79.

[31] Sharma, Y., Bhaskar, S. and John, K. (2010). Application of an Efficient Non-Conventional Heterogeneous Catalyst for Biodiesel.

[32] Alhassan, Y., Kumar, N., Bugaje, I. and Mishra, C. (2014). Optimization of Gossypium arboreum Seed Oil Biodiesel Production by Central Composite Rotatable Model of Response Surface Methodology and Evaluation of its Fuel Properties, Journal of Petroleum Technology and Alternative Fuels, 5 (1), 1-12.

[33] Goyal, P., Sharma, M. P. Jain, S. (2013). Optimization of transesterification of Jatropha curcas Oil to Biodiesel using Response Surface Methodology and its Adulteration with Kerosene Journal of Materials and Environmental Science 4 (2) 277-284 ISSN: 2028-2508 CODEN: JMESCN.

[34] Noordin, M., Venkatesh, V., Elting, S. and Abdullah, A. (2004). Application of Response Surface Methodology in Describing the Performance of Coated Carbide Tools when Turning AISI 1045 Steel, Journal of Material Proc. Technol., 1451, 46-58.

[35] Basri, M., Rahman, N., Ebrahimpour, A., Salleh, A., Gunawan, E. and Basyyaruddin, M. (2010). Comparison of Estimation Capabilities of Response Surface Methodology (RSM) with Artificial Neutral network (ANN) in Lipase-Catalysed Synthesis of Palm-Based Wax Ester, BMC Biotechnology. 7 (53), 1-14.

[36] Abdullah, A. Z., Razali, N., Lee, K. T. (2009). Optimization of Mesoporous K/SBA-15 Catalyzed Transesterification of Palm oil using Response Surface Methodology. Fuel Process. Technol. 90, 958-964.

[37] Ahmed, I., Ayman, A., Mohamed, A. and Ahmed, M. (2016). Biodiesel Production by Aspergillus niger Lipase Immobilized on Barium Ferrite Magnetic Nanoparticles, Journal of Bioengineering, 3 (14), 1-15.

[38] Felizardo, P., Correia, M., Raposo, I., Mendes, J., Rui, B. and Bordado, J. (2006). Production of Biodiesel from Waste Frying Oils, Journal of Waste Management, 26, 487-494.

[39] Radha, K. and Manikandan, G. (2011). Novel Production of Biofuels from Neem Oil, World Renewable Energy Congress, 471-478.

[40] Oyerinde, A. and Bello, E. (2016). Use of Fourier Transformation Infrared (FTIR) Spectroscopy for Analysis of Functional Groups in Peanut Oil Biodiesel and Its Blends,
British Journal of Applied Science \& Technology, 13 (3), 1-14.

[41] Roseli, A., Anna, L., Turtelli, P., and Kil, J. (2011). Biodiesel Production and Quality, Food Technology Institute and Campinas State University, Brazil Synthesis from Pongamia pinnata Oil, Energy Fuels, 3 (8), 3223-3231.

[42] Cancela, Á., Maceiras, R., Alfonsín, V. and Sánchez, Á. (2015). Transesterification of Waste Frying Oil under Ultrasonic Irradiation, European Journal of Sustainable Development, 4, 401-406.

[43] Fátima, S. Marina, C., Rubén, L., Rubén, E. and Eliseo, P. (2017). An Improvement in Biodiesel Production fromWaste Cooking Oil by Applying Thought Multi-Response Surface Methodology Using Desirability Functions, Journal of Energies, 10, 130.

[44] Richa, S., Prateek, S., Dinesh, B. and Savita, K. (2012). Optimization of Biodiesel Production by Response Surface Methodology and Genetic Algorithm, Journal of ASTM International, 9 (5), 1-2.

[45] America Society for Testing and Materials (ASTM International) (2012). Testing Methods. 190 Howard St, Ste 404 Franklin, PA-USA 16323-2362, Info@wetestII.com

[46] Mostafaei, B., Ghobadian, B., Barzegar, M. and Banakar, A. (2013). Optimization of Ultrasonic Reactor Geometry for Biodiesel Production using Response Surface Methodology, $J$. Agr. Sci. Tech., 15, 697-708.

[47] Chhetri, A., Watts, K. and Islam, M. (2008). Waste Cooking Oil as an Alternate Feedstock for Biodiesel Production, Journal of Energies, 1, 3-18.

[48] Xiaohu, F., Xi, W. and Feng, C. (2011). Biodiesel Production from Crude Cottonseed Oil: An Optimization Process Using Response Surface Methodology, Journal of Open Fuels Energy Science, 4, 1-8.

[49] Widayat, W. Darmawan, T. Hadiyanto, H. and Ar-Rosyid, R. (2018). Preparation of Heterogeneous $\mathrm{CaO}$ Catalysts for Biodiesel Production, International Conference on Energy Sciences (ICES 2016) IOP Publishing, IOP Conf. Series: Journal of Physics: Conf. Series 877, 1-8.

[50] Hilber, T.; Ahn, E.; Mittelbach, M.; Schmitd, E. Animal Fats perform Well in Biodiesel, Render Magazine, Technical Review and Life-Cycle Analysis, Renewable Energy, 35, 1-13.

[51] Shrestha, D., Van Gerpen, J. and Thompson, J. (2008). Effectiveness of Cold Flow Additives on various Biodiesels, Diesel and their Blends, Trans. ASABE, 51, 1365-1370.

[52] Dunn, R. (2015). Cold Flow Properties of Biodiesel: A Guide to Getting an Accurate Analysis, Biofuels Journal, 6, 115-128.

[53] Ibiari, N., El-Enin, S., Attia, N. and El-Diwani, G. (2010). Ultrasonic Comparative Assessment for Biodiesel Production from Rapeseed, J. Am. Sci., 6, 937-943.

[54] Gajendra, K., Kumar, D., Shailandra, S., Kothari, S. Sumit, B. and Chandra, P. (2010). Continuous Low Cost Transesterification Process for the Production of Coconut Biodiesel, Journal of Energies, 3, 43-56.

[55] Kanthawut, B., Sawitri, C., Vittaya, P. and Pinya, S. (2013). Optimization of Biodiesel Production from Jatropha Oil (Jatropha curcas L.) using Response Surface Methodology, Journal of Natural Science, 44, 290-299. 